\title{
Tanzanian mushrooms and their uses 1. Russula
}

\author{
MARJA HÄRKÖNEN, BART BUYCK, TIINA SAARIMÄKI and LEONARD MWASUMBI
}

\begin{abstract}
HÄRKÖNEN, M., BUYCK, B., SAARIMÄKI, T. \& MWASUMBI, L. 1993: Tanzanian mushrooms and their uses 1. Russula. - Karstenia 33:11-50. ISSN 0453-3402

A brief introduction of the project on Tanzanian edible mushroom is given along with the main features of the soil and vegetation of the collecting sites. The importance of Russulaceae in Africa and the collected Russula species are discussed. Thirty-six specimens of Russula were collected between 1989-1991, and of this material, 21 species of Russula were identified. Nineteen species are reported from Tanzania for the first time. $R$. tenuithrix Buyck sp. nov., R. tanzaniae Buyck sp. nov., $R$. hiemisilvae Buyck sp. nov. $R$. sublaevis (Buyck)Buyck stat. nov. and nine other species were found in woodlands, R. usambarae Buyck sp. nov., R. acriannulata Buyck sp. nov. and five other Russula in lower montane forest. One species has been introduced in Pinus plantations. Along with a key to the collected Russula species, their systematic position, distribution and possible host trees are discussed and compared with earlier data from Tanzania and other African countries. A discussion on the edibility of Russula is also included.
\end{abstract}

Key words: Africa, Agaricales, ethnomycology, Russula, Tanzania, taxonomy

Marja Härkönen and Tïna Saarimäki, Department of Botany, P.O. Box 7, FIN-00014 University of Helsinki, Finland

Bart Buyck, Faculty of Science, University of Burundi, P.O. Box 2700 Bujumbura, Burundi

Leonard Mwasumbi, Department of Botany, University of Dar es Salaam, P.O. Box 35060, Dar es Salaam, Tanzania

\section{Contents}

Introduction 11

Material and methods …......................................... 14

Collecting .............................................................. 14

Interviews ….................................................. 15

Handling of the material ..................................... 16

Russula ............................................................... 16

Introduction .................................................... 16

Importance of the Russulaceae in tropical

Africa ............................................................. 16

Tanzanian species of Russula ................................ 17

Key to the known species of Russula in Tanzania

Habitats of Russula in Tanzania ............................... 41

Montane forests .................................................... 41

Miombo woodlands ............................................ 41

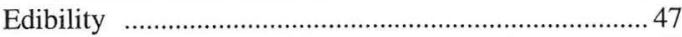

Edibility of Russula species in Tanzania ............ 47

Edibility of Russula species elsewhere ............... 47

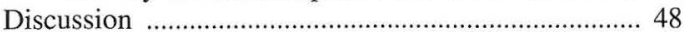

Acknowledgements .................................................... 49

References ............................................................. 49

\section{Introduction}

In modern times rapid urbanization and loss of the traditional way of living are in progress all over the world. Collection of ethnobotanical knowledge regarding native people is an urgent task. No work has been done thus far in Tanzania concerning use of mushrooms.

Tanzania lies in eastern Africa between latitudes $1-11^{\circ}$ south of the Equator (see Fig. 4). Its area is about $945000 \mathrm{sq} \mathrm{km}$. Hot and humid tropical lowlands are found along the coast, but a major part of the country consists of high plateau at the altitude of ca. $1000 \mathrm{~m}$, which is cool during the rainy seasons. There are also mountains with all climatic zones up to regions of permanent ice on Mt Kilimanjaro. The leeward western sides of the mountains are mostly arid, because prevailing winds blow from the Indian Ocean in the east. There are two rainy seasons in northern Tanzania, 


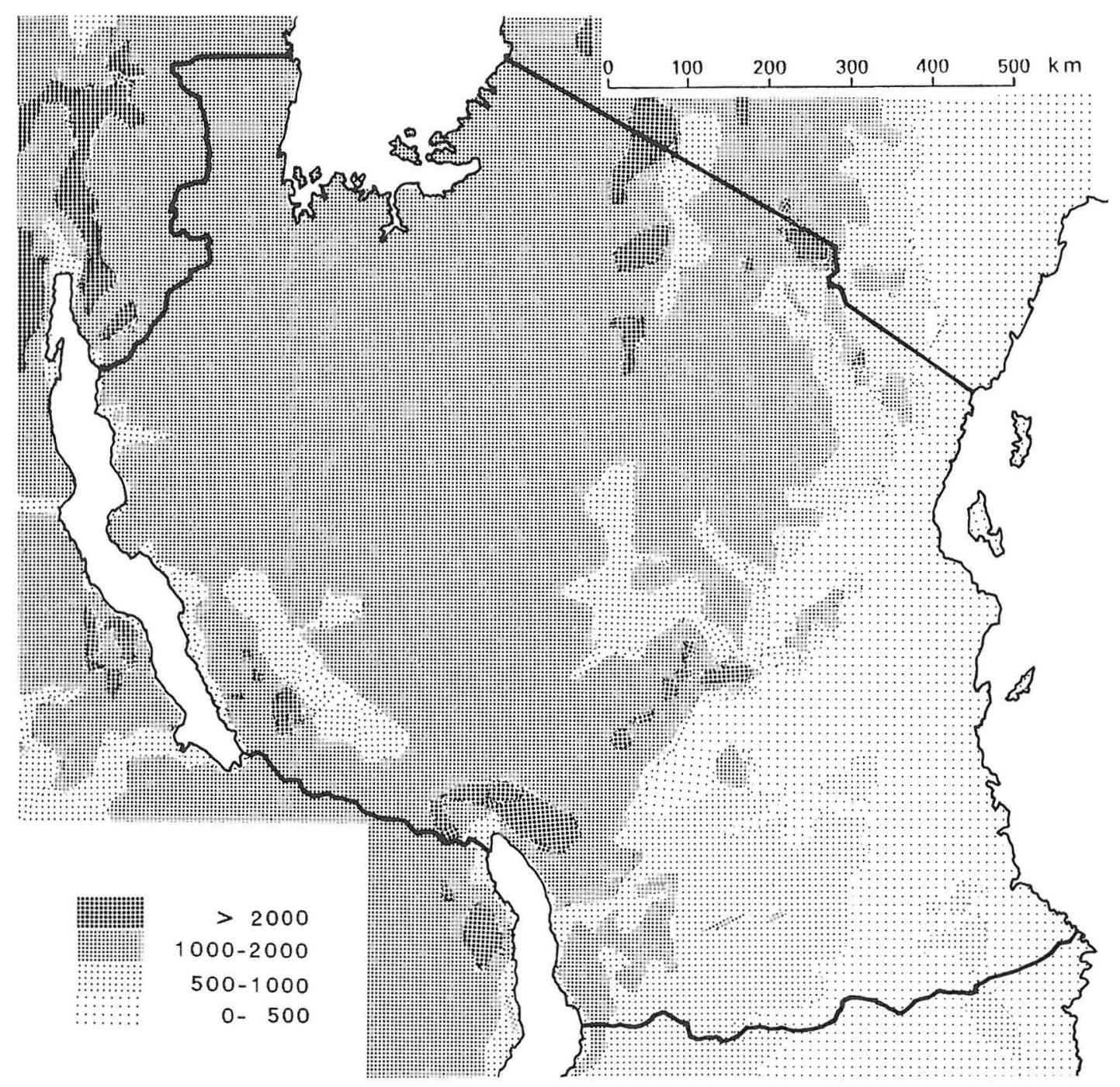

Fig. 1. Tanzania. Altitude, meters above sea level. All maps compiled from Berry (1975), Anonymous (1987) and White (1983).

the so-called short rains in November-December and long rains in April-May. South-eastern slopes of the mountains may get rains any time of the year. As for southern Tanzania, it has only one rainy season, which usually begins in January. Because of the varying topography and climate there is a wide variation in vegetation from rain forests to semideserts (see Figs. 1-3).
The population of Tanzania is about 24 million (Anonymous 1990), with about 120 tribes, each of which has a language of its own (Berry 1975). The largest of these is Sukuma, comprising about $12 \%$ of the population; none of the others exceeds $4 \%$. In addition to their mother tongue, most people can speak Swahili, and many even English, the two official languages. 


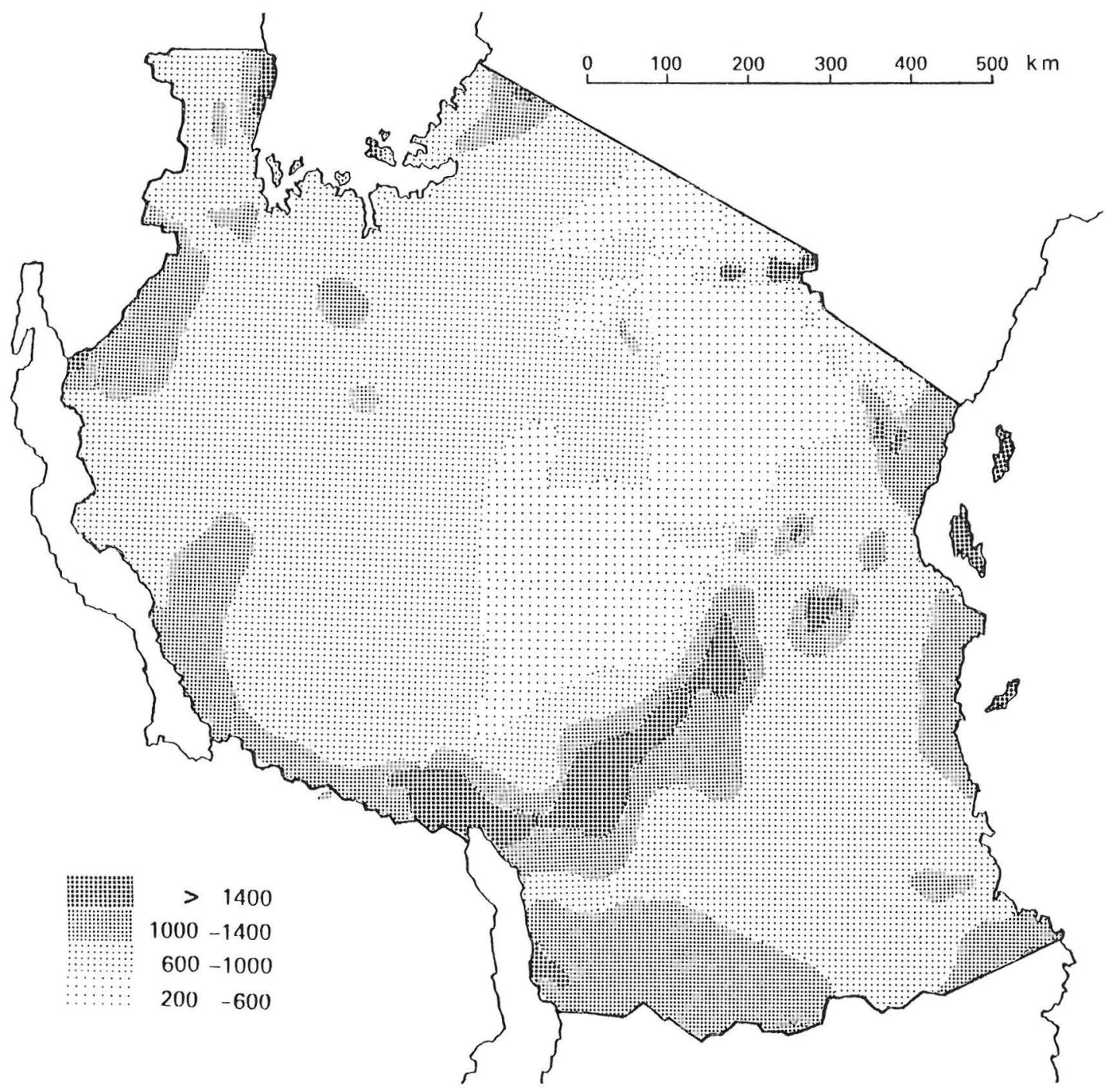

Fig. 2. Tanzania. Average annual precipitation in millimeters.

After some preliminary inquiries during three field expeditions in 1988 and 1989 a research project on Tanzanian edible mushrooms and their uses was set up in 1990 jointly with the University of Helsinki in Finland and the University of Dar es Salaam in Tanzania. For more details about the framework of this research, see Härkönen et al. (1993a, b).

In this paper Härkönen and Saarimäki have written the following chapters: Introduction, Material and methods, and Edibility. Buyck is responsible for the chapter Russula, and Mwasumbi for Habitats of Russula in Tanzania. The discussion has been compiled by the first three authors. Line drawings referred to in the descriptions were done by Buyck, SEM photos by Salo and Saarimäki, and other photos and maps by Härkönen and Saarimäki. 


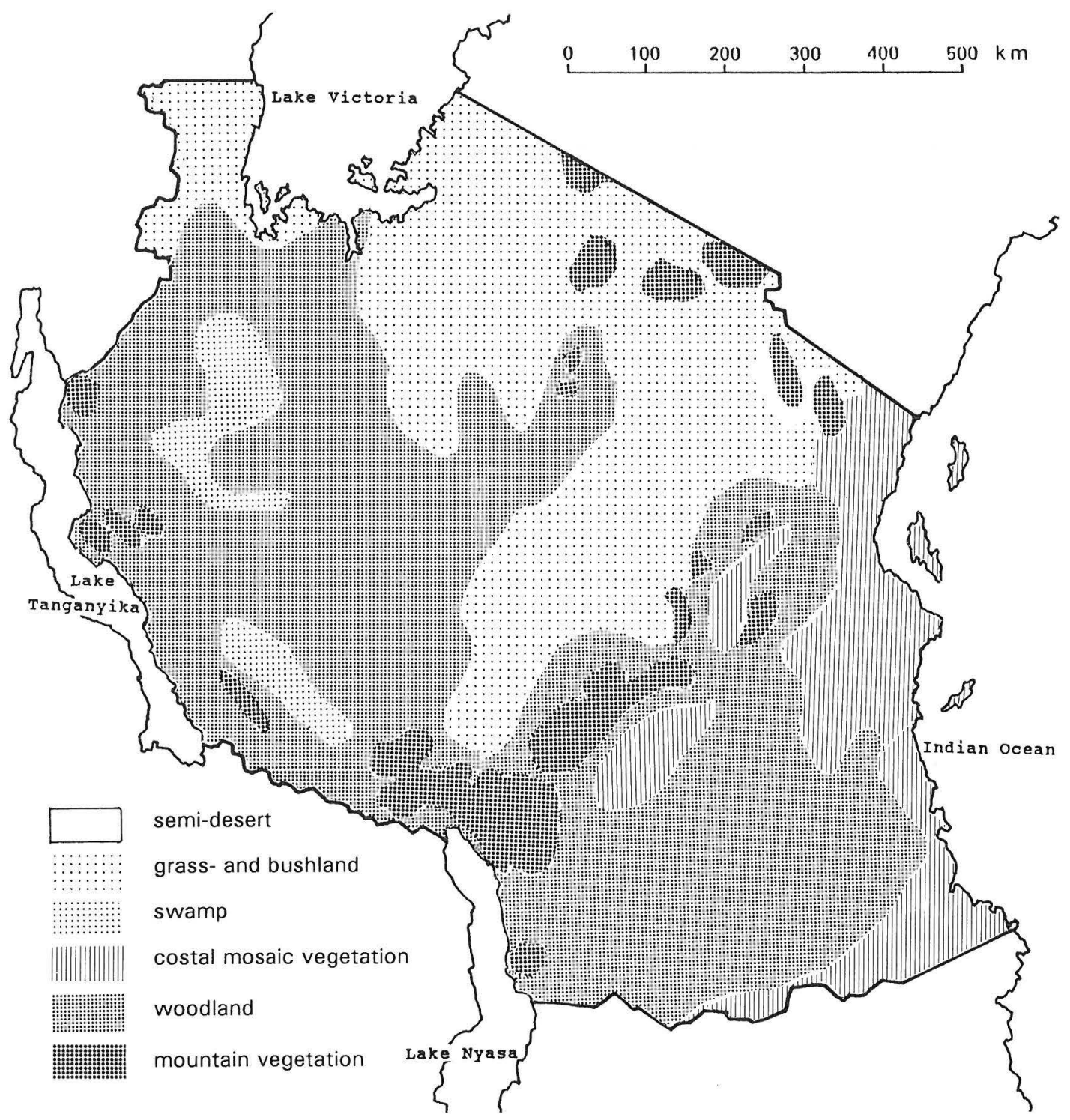

Fig. 3. Tanzania. Generalized distribution of original vegetation.

\section{Material and methods}

\section{Collecting}

To determine habits of mushroom use, the authors Härkönen and Saarimäki from Finland and Mwasumbi from Tanzania made three collecting trips to Tanzania in 1990 and 1991, all during the rainy seasons. Fig. 4 shows the areas of the tribes visited thus far. One further field expedition will be made in 1993 .
In villages we contacted local people and went with them to pick mushrooms. Afterwards we collected vernacular names for the mushrooms from the villagers, interviewed them and studied how mushrooms were prepared for food. When possible, we also ate mushroom dishes ourselves. Voucher specimens were preserved, their fresh characters were recorded, and they were dried with a field drier to be later identified at the University of Helsinki. Mushrooms were also purchased for specimens along roadsides and in market places. 


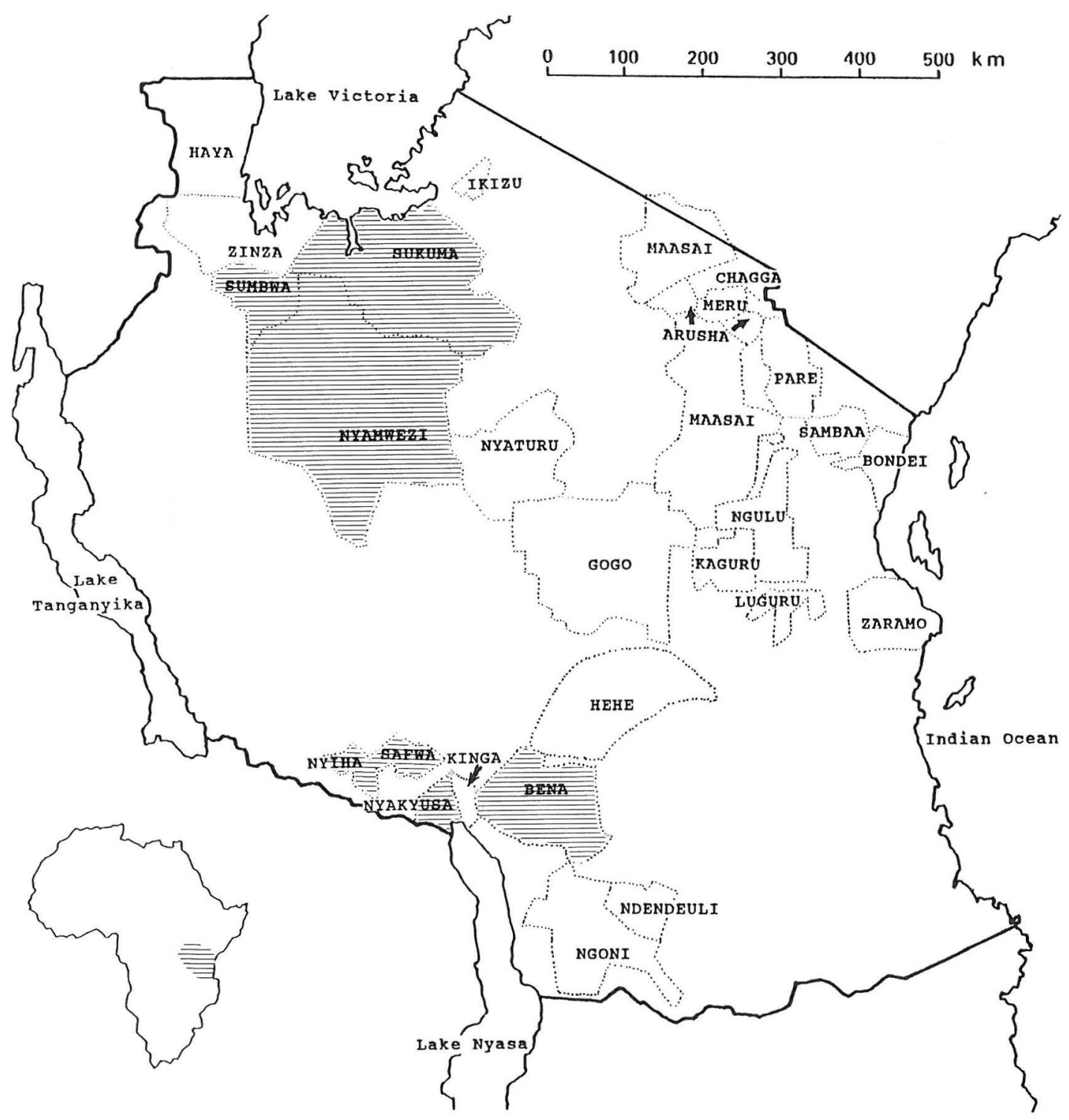

Fig. 4. Map showing distribution of the tribes visited during the first three collecting trips. Shaded areas show tribes which use Russula species for food.

\section{Interviews}

Interviews were held in Swahili or in English or in some cases in local languages. To standardize the information collected from different tribes, the same set of questions was always asked as follows:

Personal details: Name, address, sex, age, tribe, vernacular language, occupation, length of time the family has lived in the area.

Specific questions: Do you eat mushrooms? Do you collect mushrooms yourself or who in your family collects them? Who taught you how to collect them? How many different kinds of mushrooms do you collect for food? Please list the names of the mushrooms now on hand or tell us what species you can recognize. Which species tastes the best? Is everyone here allowed to collect mushrooms everywhere? When and how often are the mushrooms collected? How do people prepare mushrooms for food? Who in your family prepares mushrooms for food? How highly do you value mushrooms as food if compared to 
other foodstuffs such as meat, fish or vegetables? Do you preserve mushrooms? How? Which species? Are mushrooms offered for sale in the market places in this region? Do you use mushrooms for other purposes than for food, for instance as medicine? Is there a traditional healer in your village who uses mushrooms? How does he use them? Are there poisonous mushrooms in this region? Have misidentifications occurred, leading to mushroom poisonings? How do you recognize a poisonous mushroom? Do you know any beliefs, stories or fairy-tales about mushrooms?

So far 81 interviews have been held and transcribed from the recorded tapes and field notes. They are included in full in the first two progress reports for the Finnish International Developmental Agency of the Ministry for Foreign Affairs of Finland (FINNIDA) and for the Tanzanian Commission for Science and Technology. Some preliminary conclusions about mushroom-use by the Tanzanians have been compiled by Härkönen (1992) and Härkönen et al. (1993b).

\section{Handling of the material}

During all our trips we have collected about 1000 specimens of fungi, edible and also inedible ones. In the text collecting sites are according to Polhill (1988) and the Degree Reference System is according to Leistner \& Morris (1976). All specimens are deposited at the Botanical Museum of the University of Helsinki $(\mathrm{H})$. One article on the Myxomycetes has already been published (Härkönen \& Saarimäki 1991, 1992).

All specimens considered by the natives to be edible have been identified to genus level by the first and third authors. The identification is continued to the species level and results will be published gradually, if possible jointly with the aid of specialists in specific groups. In August, 1992, Bart Buyck, a specialist in African Russulaceae, visited the University of Helsinki to work on the 36 Russula specimens collected from Tanzania thus far.

\section{Russula}

\section{Introduction}

Russula is the type genus of the Russulaceae Lotsy. In its classic concept, this family comprises the agaricoid genera Lactarius and Russula, the former differing in the field principally by the exudation of a milky latex on injury, the usually decurrent lamellae and the quasi absence of brightly coloured basidiomes. The Russulaceae differ from the other lamellate Basidiomycotina (Agaricales) by having spherocytes in the context. These spherocytes also explain the brittle, not fibrous nature of the flesh of the Russulaceae. Several taxa producing secotioid or hypogeous basidiomes (Elasmomycetaceae sensu Pegler \& Young) or even poroid basidiomes (Bondarzewiaceae Kotl. \& Pouzar) have been linked with the Russulaceae because of their similar spherocytes, the possession of amyloid ornamentation on the spores or sulfoaldehyde-sensitive (sulfovanilline [SV] is most used) cystidia or laticifers, which are all characteristic features of the Russulaceae.

Study of the Russulaceae requires several reagents for macroscopic and microscopic examination. The morphological diversity of microscopic structures has given rise to a rich terminology. We refer to Romagnesi (1967, 1985), Singer (1986) and, particularly for the tropical species, to Buyck (1989a, 1991a, b) for explanation of the use of reagents and the methodology of examination.

Although microscopic features have become more important in recent decades, present classifications of the genus Russula are based largely on such macroscopic features as spore colour, smell and taste, or the alteration of the colour of the context that have often not been noted for the African material. It is both possible and necessary - even for the better-known Russula floras from Europe or North America to exploit the microscopic features more than is actually done for the delimitation of the various taxa, but good illustrations are a prerequisite for reliable comparison and correct interpretaton of microscopic features. As macroscopic features are desirable for identification in the field, these have been used in the key below. Microscopic structures are illustrated for all the species to confirm field identifications.

Importance of the Russulaceae in tropical Africa

Various authors (Hennings 1901, 1902, Patouillard 1914, 1927, Beeli 1928, 1936, Singer 1935, 1942, 1955, 1973, Heim 1938b, 1943, 1968, 1970, 1971, Perreau 1983, Buyck 1988, 1989bd, 1990a, b) occasionally have described one or more tropical African Russulae, but apart from 2 major contributions - one on the Russulaceae of Madagascar (Heim 1938a) and a recent one on the genus Russula in Central Africa (Buyck 1989e, 1993b) - no other taxonomic studies on African Russulaceae have been made.

The Russulaceae are extremely common in most of the lowland rain forest and among the woodland vegetation of Africa. By number of described species, the Russulaceae are the most 
important ectomycorrhizal partners of trees in the tropical lowlands of Africa. For the GuineoCongolian domain, 65 Russula and 21 Lactarius species have been described. When taking also the surrounding woodlands of the Sudano-Zambezian domain into consideration, the total number of tropical African Russula species amounts presently to 129 (Buyck 1992), outnumbering by far the 31 and 12 Russulae described from the lowland neotropics (Singer et al. 1983) and the Lesser Antilles (Pegler 1983) respectively. Recent inventories in the rain forest of Cameroon (Watling, pers. comm.) and the woodlands of Zambia, Burundi and Malawi still reveal many undescribed species (Buyck, unpubl.).

For East Africa only three native Russulae were known (Pegler 1977, Morris 1990). Both these publications as well as some of the earlier contributions on Central African Russulaceae (Beeli 1928, Heim 1938a) cite several Russulaceae that have originally been described from Europe.

\section{Tanzanian species of Russula}

The only published records of Russula for Tanzania are those in "The preliminary agaric flora for East Africa" (Pegler 1977). Among these, $R$. emetica (Schaeff.) Pers.: Fr., R. fragilis (Fr.) Fr. and $R$. atropurpurea (Krombh.) Britzelm. are not accepted here because they almost certainly are based on misidentifications. $R$. deremensis Hennings, described from the Usambara Mts, Tanzania, and $R$. cinerella Pat., described from Madagascar, present problems, because the type material is either lost $(R$. deremensis) or in too poor a condition to study ( $R$. cinerella), and correct interpretation is difficult without a modern description. We can doubt the presence of $R$. cinerella in Tanzania because the illustration by Heim (1938a: fig. 42) of the spore ornamentation of the type is quite different from the ornamentation of the specimen described from Tanzania by Pegler under this name. Buyck has seen the specimen described by Pegler in the Kew Herbarium, and the exsiccatum matches $R$. subfistulosa Buyck exactly.

The systematic arrangement of the collected species (Table 1) is according to Buyck (1992). Several subsections are placed only provisionally in a section, especially in section Heterophyllae, because examination of fresh material is needed to complete the description with regard to the nature of pigmentation or organoleptic features. At subsectional level, however, the groups are probably very homogeneous and natural.

All Tanzanian Russula species are discussed below in alphabetical order. We did not study the collections described by Pegler (1977). Indication of likely hosts for the various Russula species is based on observations of the position of the carpophores and result usually from the second author's personal experience.

Indication of spore size (only for the new species) includes 20 measurements excluding ornamentation. Maximum and minimum measurements are given in brackets, mean size is underlined and accompanied by standard deviation; relation length/width of the spores is added $(\mathrm{Q})$, in the form of mean value with standard deviation. Macroscopic notes are those of the collectors, microscopic descriptions are based on observations made of samples stained with Congo Red, usually after a brief $\mathrm{KOH}$-solution treatment.

\section{Key to the known species of Russula in Tanzania}

(Features included are from the Tanzanian specimens.)

1. Occurring in pine plantations, pileus up to $70 \mathrm{~mm}$ in diam, greyish brown with rusty spots, strongly striate near margin, lamellae cream; stipe white, turning greyish at base, taste mild $R$. pectinatoides

1. Occurring in natural vegetation (2)

2. Annulate species, remnants of the partial veil might eventually remain attached to the pileus margin

2. Without annulus ....................................... (5)

3. Taste acrid after some time, pileus up to $40 \mathrm{~mm}$ in diam, ochraceous, bruising brown; lamellae white, with lamellulae; stipe white, tapering towards the base $R$. acriannulata

3. Taste mild, pileus more than $40 \mathrm{~mm}$ in diam ..... (4)

4. Pileus $50-60 \mathrm{~mm}$ in diam, greyish violet, lamellae cream, in woodland .................... R. hiemisilvae

4. Pileus up to $55 \mathrm{~mm}$ in diam, violet-brown, lamellae white with a lilac tint near the edge, in moist montane forest ..................... R. annulata

5. Lamellulae abundant

5. Lamellulae absent or rare .................................. (9)

6. Lamellae and/or lamellulae not remarkably crowded, taste mild; flesh bruising reddish or brown with age or when cut, with distinct smell; pileus $90-110 \mathrm{~mm}$ in diam ....................... (8)

6. Lamellae and lamellulae densely crowded, taste acrid; flesh bruising or not but never strongly so, pileus usually smaller .. (7)

7. Pileus brown or yellowish brown, $>50 \mathrm{~mm}$ in diam., lamellae white with brown edge ......R. subfistulosa 
7. Pileus cream, $<40 \mathrm{~mm}$ in diam, lamellae yellowish with concolorous edge R. tanzaniae 8. Spores ellipsoid, distinctly cristate-subreticulate R. phaeocephala

8. Spores ellipsoid, almost smooth, very faintly and densely cristate-reticulate .................. R. heimii

9. Lamellae frequently and distinctly forked ....... (10)

9. Lamellae never or only exceptionally forked ... (11)

10. Firm species with yellow to greyish yellow pileus, $30-60 \mathrm{~mm}$ in diam, fissuring towards the margin and with a characteristic brownish tomentum near the base of the stipe; pellis peelable, resembling an epithelium; flesh chambered in stipe, without special odor, mild; lamellae thin, crowded, white ...... $R$. cellulata
10. Pileus $85-90 \mathrm{~mm}$ in diam, light yellow-brown to grey, with incurved margin; pellis peeling halfway, sticky when moist; stipe almost white; flesh without special odour, mild; lamellae close, thin and narrow, whitish with pinkish tone

R. liberiensis

11. Colour of the pileus at least partially reddish, violaceous or pinkish

11. Colour of the pileus without any reddish, violaceous or pinkish tint ............................................. (16)

12. Stipe distinctly reddish all over; pileus small ( $<50 \mathrm{~mm}$ in diam), taste mild

12. Stipe basically whitish, eventually greyish, brownish or yellowish with age or on bruising; pileus usually larger (14)

Table 1. Systematical arrangement of the Tanzanian Russula species

\begin{tabular}{|c|c|c|}
\hline Section & Subsection & Species \\
\hline \multirow[t]{2}{*}{ Compactae Fries } & Nigricantes Bataille & R. phaeocephala \\
\hline & Ingentinae Buyck & R. heimii \\
\hline Plorantes Bataille ex Singer & Archaeinae (Heim ex Romagn.) Buyck & R. tanzaniae sp. nov. \\
\hline \multirow[t]{2}{*}{ Fistulosae Buyck } & Fistulosinae Heim ex Singer & $\begin{array}{l}\text { R. subfistulosa } \\
\text { R. cinerella sensu Pegler } 1977\end{array}$ \\
\hline & Testaceoaurantiacinae Buyck & R. cf. tuberculosa (fide Pegler 1977) \\
\hline \multirow[t]{2}{*}{ Ingratae Quélet } & Pectinatinae Bon & $R$. pectinatoides \\
\hline & Foetentinae Melzer \& Zvara & $R$. deremensis \\
\hline \multirow[t]{5}{*}{ Heterophyllae Fries } & Brunneodermatinae Buyck & $\begin{array}{l}R . \text { cellulata } \\
R . \text { liberiensis } \\
R . \text { tenuithrix sp. nov. }\end{array}$ \\
\hline & Guayarenses Singer & R. usambarae sp. nov. \\
\hline & Ilicinae (Romagn.) Buyck & R. albofloccosa \\
\hline & Heterophyllinae (Maire) Schaeffer & $\begin{array}{l}R . \text { annulata } \text { s.l. } \\
R . \text { hiemisilvae } \text { sp. nov. } \\
R . \text { sublaevis stat. nov. }\end{array}$ \\
\hline & Paradermatinae Buyck & R. acuminata \\
\hline \multirow[t]{3}{*}{ Crassotunicatae (Singer) Singer } & Amoeninae Singer ex Buyck & R. ciliata \\
\hline & Echinospermatinae Buyck & R. echinosperma \\
\hline & Aureotactinae Heim ex Buyck & R. acriannulata sp. nov. \\
\hline \multirow[t]{2}{*}{ Polychromae Maire } & Luteomaculatinae Buyck & $\begin{array}{l}R . \text { compressa } \\
R . \text { sesenagula }\end{array}$ \\
\hline & incertae sedis & R. testacea \\
\hline Constantes Singer & Sardoninae Singer & R. congoana \\
\hline
\end{tabular}


13. Lamellae yellowis . R. congoana var. congoana

13. Lamellae whitish with pinkish tint .. $R$. acuminata 14. Lamellae white; pileus $65 \mathrm{~mm}$ in diam, dull red; pellis half-way peeling $R$. echinosperma

14. Lamellae yellowish at maturity ...............(15)

15. Fragile species of moist forest; taste slightly peppery; pileus ca. $30 \mathrm{~mm}$ in diam, unevenly dark red, slightly pruinose, with pellis entirely separable and detached at margin; stipe yellowing with a very faint reddish tone ......................... R. sesenagula

15. Fragile woodland species; taste mild, usually no particular smell; pileus $25-70 \mathrm{~mm}$ in diam, bright red, shiny, with pellis entirely separable; stipe white, sometimes bruising slightly brownish at base ..

R. compressa

16. Lamellae white or pale cream ............... (17)

16. Lamellae with an ochre tint; pileus $60-70 \mathrm{~mm}$ in diam, light brown, darker at the center, dull, finely cracked pellis, striate towards the margin; stipe usually shorter than the pileus diam, base concolorous, becoming paler towards the top; taste mild; smell weakly sour

R. testacea

17. Pileus cream or bright yellow-green (18)

17. Pileus with dominant greyish or brownish tints (20)

18. Pileus cream-coloured, with distinct appressed pellicules, $55-70 \mathrm{~mm}$ in diam, mild, without smell R. albofloccosa

18. Pileus more distinctly coloured, smooth or pruinose

(19)

19. Fruit bodies small; pileus $20-40 \mathrm{~mm}$ in diam, dull, olive golden to yellow or bright yellow-green; stipe tapering downwards, faintly yellowish, especially after handling .......................................... R. ciliata

19. Fruit bodies medium-sized; pileus bright yellow, 30-60 mm in diam; stipe subcylindrical, white ... $R$. sublaevis

20. Pileus greenish grey with grey stipe; spores with low but distinct warts, locally confluent, forming small ridges [if almost smooth spores with minute isolated warts: $R$. cinerella] .....

R. tenuithrix

20. Pileus brown to orange brown or even bright orange (21)

21. Bright orange pileus and stipe, at least in mature specimens ............................. $R$. aff. tuberculosa

21. Pileus brown to orange-brown ..................... (22)

22. Taste acrid and distinct disagreeable smell; gill edge concolorous with sides of lamellae .......

..R. deremensis

22. Taste faintly acrid after a while; without smell; gill edge distinctly brown ......R. usambarae

1. Russula acriannulata Buyck, sp. nov. Figs. 5, 17, 26, 29

Pileus usque ad $40 \mathrm{~mm}$ latus, ochraceus, in centro saturate brunneus; margine fortiter striatus. Lamellae albae, usque ad $3 \mathrm{~mm}$ latae, lamellulis intermixtae. Stipes annulatus, basim versus attenuatus, albus. Caro initio mitis, dein nimio acris, inodora. Sporae in cumulo colore ignotae.

Sporae subglobosae, (8.4-)8.76-9.14-9.53(9.9) $\times(7.4-) 7.78-\underline{8.11}-8.43(-8.7) \mu \mathrm{m}(\mathrm{Q}=$ $(1.08-) \underline{1.13}(-1.17)$ ), dense spinis distinctis moderate acutis isolatis usque ad $2 \mu \mathrm{m}$ altis generaliter fortiter amyloideis verrucis valde parvioribus intermixtis ornatae; macula suprahilare indistincta, verrucis parvis ornata. Basidia voluminosa, 35-55 x 12-16 $\mu \mathrm{m}$, tetraspora; sterigmata fortia. Cystidia abundantia in acie lateribusque, $35-65 \times 6-10 \mu \mathrm{m}$ in acie, longioria in lateribus, emergentia, clavata, capitulata, contentu distincta SV+ repleta, tenuitunicata. Trama lamellarum spherocystis endocyst idiisque cylindratis efformata. Pileipellis angusta; subpellis paulum trama differentiata, hyphis tenuibus leviter incrustatis cystidiisque longissimis numerosis 6-9 $\mu$ m latis, obtusis vel capitatis, contentu distincta repletis composita; suprapellis hyphis tenuibus $3-5 \mu \mathrm{m}$ diam. subcylindratis gracilibus dense septatis plus minusve in trichoderma agregatis pileocystidiisque numerosis anguste cylindratis, $15-85 \times 3-5 \mu \mathrm{m}$, capitulatis contentu distincta repletis composita. Stipitipellis hyphis cystidiisque numerosis pileipelli comparandibus efformata.

Holotypus: Tanzania. Tanga Prov.: Lushoto Distr., W Usambara Mts, Mazumbai, $\mathrm{N}$ of the Mazumbai Forest Reserve border, $\mathrm{N}$ of the Kambi Falls (04 38 DC), lower montane forest, 1680 m, 8.XII. 1989 Härkönen $10112(\mathrm{H})$.

Pileus up to $40 \mathrm{~mm}$ in diam, ochre, darker brownish in the center; margin strongly striate. Lamellae white, up to $3 \mathrm{~mm}$ broad, with lamellulae. Stipe annulate, white, tapering towards the base. Flesh very thin, at first mild, at last almost acrid, no particular smell. Spore print not obtained (probably pale).

Spores subglobose to broadly ellipsoid, (8.4)8.76-9.14-9.53(-9.9) x (7.4-)7.78-

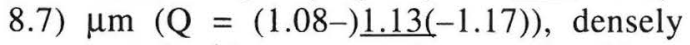
ornamented with very prominent, rather blunt, isolated verrucae, measuring up to $2 \mu \mathrm{m}$ high, usually strongly amyloid, mixed with smaller verrucae; suprahilar spot indistinct, occupied by small, weakly amyloid verrucae, becoming larger towards the margin. Basidia voluminous, 35-55 x 12-16 $\mu \mathrm{m}$, often rather short, bearing usually 4 stout sterigmata. Cystidia abundant, especially near the sterile gill edge, there 35-65 $\times 6-10 \mu \mathrm{m}$ and often staining brown, on the sides of the gills longer (but difficult to measure because of fragility), hardly emerging, clavate, 
HÄRKÖNEN, BUYCK, SAARIMÄKI \& MWASUMBI: TANZANIAN KARSTENIA 33 (1993)
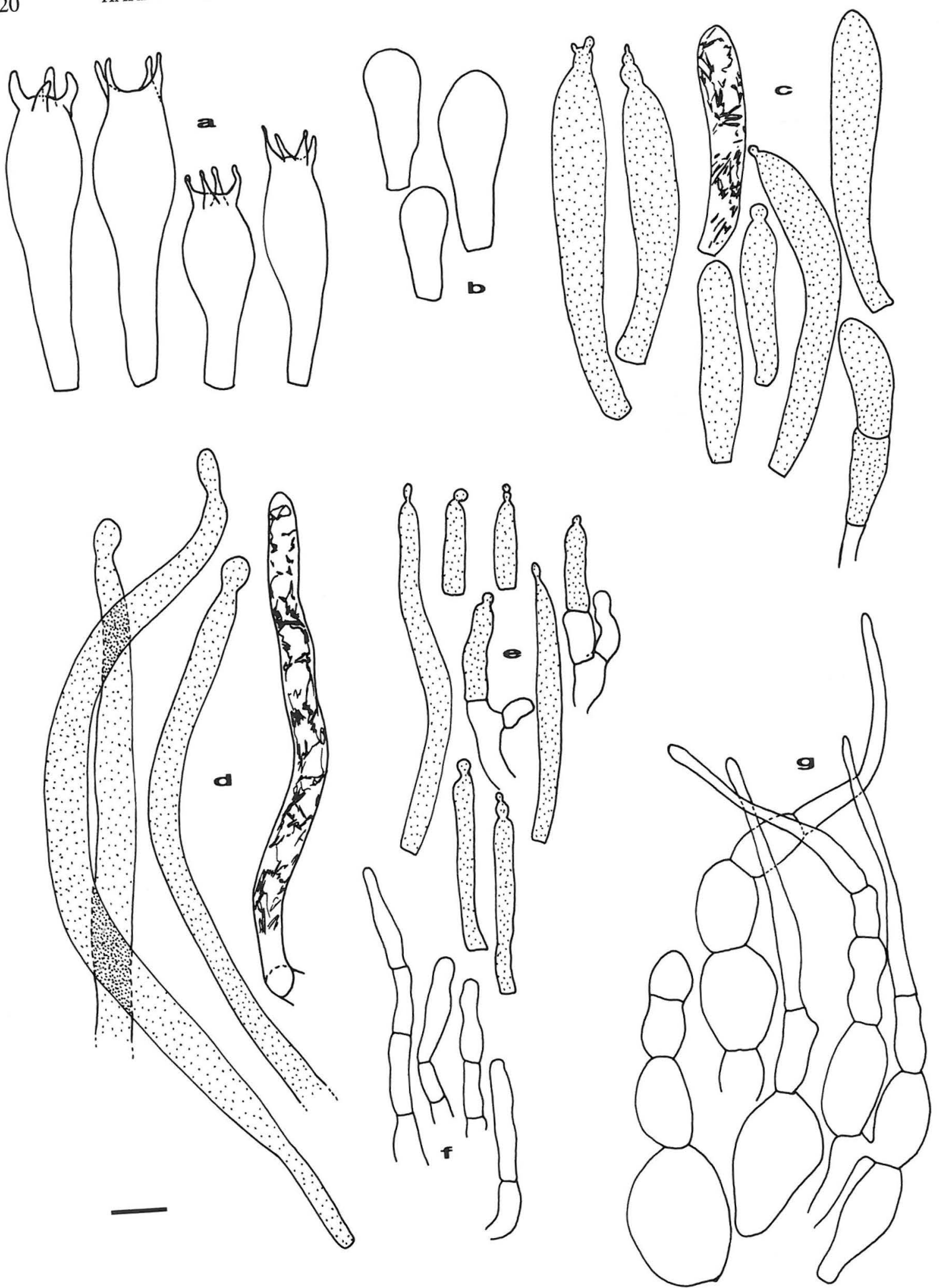
capitulate, well differentiated by abundant SV+ contents, thin-walled. Trama of the gills composed entirely of spherocytes, but with long, cylindrical endocystidia; subhymenium also cellular. Pileipellis very thin; subpellis hardly differentiated from the underlying trama, hyphae with thin but weakly encrusted walls, intermixed with very numerous and prominent dermatocystidia, these up to several hundreds of $\mu \mathrm{m}$ long, 6-9 $\mu \mathrm{m}$ in diam, broadly rounded to capitate, with distinct contents; suprapellis a loose trichoderm composed of very fragile and thin-walled elements, short-celled, more or less cylindrical, 3-5 $\mu \mathrm{m}$ thick; dermatocystidia in suprapellis very abundant, narrowly cylindrical, sometimes very short, $15-85 \times 3-5 \mu \mathrm{m}$, capitulate, with distinct contents, thin-walled. Stipitipellis very similar, caulocystidia equally abundant.

Vernacular names. Unknown.

Edibility. Unknown.

Ecology. Humid lower montane forest.

Likely hosts. Unknown.

Material examined: Tanzania. Tanga Prov.: holotype; same data, Saarimäki 421.

Observations. This is a very puzzling species, showing affinities with subsection Concolorinae Buyck (Fistulosae) by the subglobose, strongly ornamented spores, by the coloured hymenial elements near the gill edge, and by the form of the basidia, cystidia and the elements of the pileipellis, but differing principally by the possession of abundant dermatocystidia in suprapellis and in the underlying tissue continuing even into the lamellar trama. Similar presence of abundant cystidial elements in the whole of the carpophore was also described (Buyck 1993b) for several species in subsection Aureotactinae Heim ex. Buyck.

Aureotactinae is an exclusively African subsection and was transferred to section Crassotunicatae (Singer) Singer (Buyck 1992). It comprises both annulate ( $R$. xylophila Beeli, $R$. brunneoannulata Buyck, $R$. radicans Heim) and non-annulate $(R$. aureotacta Heim) species usually characterized by a strongly yellowing context. $R$. oleifera Buyck, placed previously in
Aureotactinae, should be transferred to section Ingratae Quélet, subsection Foetentinae Melzer and Zvára.

2. Russula acuminata Buyck, Bull. Jard. Bot. Nat. Belg. 58:467 (1988) — Fig. 6

Description. Buyck 1993b.

Vernacular names. Unknown.

Edibility. Unknown.

Ecology. Humid equatorial or lower montane forest.

Likely hosts. Unknown.

Material examined: Tanzania. Tanga Prov.: Lushoto Distr., W Usambara Mts, Mazumbai, N of the Mazumbai Forest Reserve border, and Kambi Falls, Kwamshundi (04 38 DC), lower montane forest, 1 710-1 800 m, 8.XII.1989 Saarimäki 426. Zaïre. Buyck (1993b).

Observations. As macroscopic observations are very limited (see key), the identification is based on microscopic features. However, both are in good agreement with the type description (Buyck 1993b). Minor differences concern mainly the ornamentation of the spores which is less crested but as well developed as in the type, and the larger diametre of the pileocystidia.

3. Russula albofloccosa Buyck, Bull. Jard. Bot. Nat. Belg. 60:199 (1990) — Fig. 7

Description. Buyck (1993b).

Vernacular names. Manifuma (Sukuma).

Edibility. Inedible (Nyamwezi, Sukuma).

Likely hosts. Burundi. Brachystegia microphylla (Buyck, unpubl.). Zambia. Uapaca kirkiana, Brachystegia spiciformis, Baphia bequeartii, Isoberlinia angolensis, Julbernardia paniculata, Albizia adianthifolia, Uapaca nitida (Buyck, unpubl.).

Material examined: Tanzania. Western Prov: Kahama Distr., $45 \mathrm{~km}$ SW of Kahama, Mpunze, Forest Reserve (03 $32 \mathrm{CD})$, on soil in woodland, $1150 \mathrm{~m}$, 10.XII.1991 Saarimäki et al. 1041. Tabora Distr., $10 \mathrm{~km} \mathrm{~S}$ of Tabora, Kipalapala (05 $32 \mathrm{BB}$ ), on soil in miombo woodland, 1200 m, 12.XII.1991 Saarimäki et al. 1067; 40 $\mathrm{km} \mathrm{S}$ of Tabora, between Tabora and Urambo (05 $32 \mathrm{AB})$,

Fig. 5a-g. - a-f. Russula acriannulata (type), g. R. ciliata (1022). — a: basidia, b: basidiola, c: hymenial cystidia, d: dermatocystidia of subpellis of pileus center, e: dermatocystidia of suprapellis of pileus center, $\mathrm{f}, \mathrm{g}$ : hyphal extremities of pileus center. $\mathrm{Bar}=10 \mu \mathrm{m}$. 


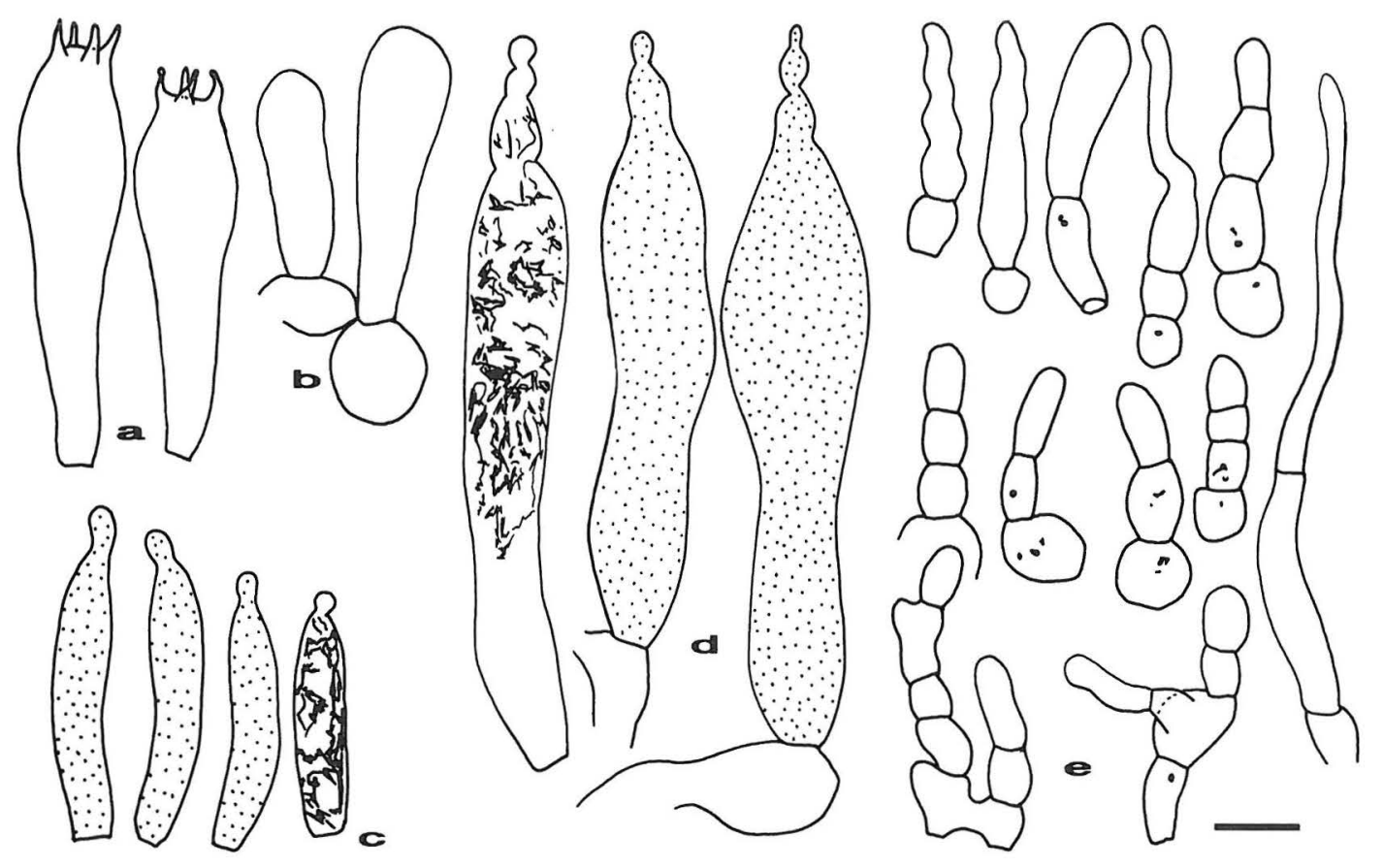

Fig. 6a-e. Russula acuminata (426). - a: basidia, b: basidiola, c: dermatocystidia of suprapellis of pileus center, d: hymenial cystidia, e: hyphal extremities of pileus center. $\mathrm{Bar}=10 \mu \mathrm{m}$.

in miombo woodland, $1100 \mathrm{~m}, 13 . \mathrm{XII} .1991$ Saarimäki et al. 1078. Zaïre, Burundi. Buyck (1993b). Zambia. Buyck (unpubl.).

Observations. A typical species of miombo woodland, probably occurring all over the Zambesian domain, often in large numbers. It is easily recognized by the pale yellowish and later cream-coloured to almost white pileus covered with appressed, usually paler pellicules. There is no specific smell, and the taste is mild for all 3 Tanzanian specimens, but has been noted to become faintly acrid after a while in collections from Zaïre (Buyck 1993b).

The microscopic features are very similar in specimens from all countries (see also discussion under $R$. sublaevis). Typical features include the low number of lamellar cystidia with a faintly positive sulfovanilline reaction and a very fragile wall; the suprapellis, which is fragmented into appressed pellicules, contains subulate, mucronate pileocystidia and has a virescens-structure, but long cylindrical pileocystidia are present in the subpellis and in the underlying trama.
4. Russula annulata Heim, Candollea 7:392 (1938) — Figs. 8, 17

Description. Buyck (1993b), Heim (1938a).

Vernacular names. Unknown.

Edibility. Unknown.

Ecology. Humid equatorial or lower montane forest.

Likely hosts. Unknown, possibly Gilbertiodendron dewevrei in Zaïre.

Material examined: Tanzania. Tanga Prov.: Lushoto Distr., W Usambara Mts, Mazumbai, N of the Mazumbai Forest Reserve border, and Kambi Falls, Kwamshundi (04 38 DC), lower montane forest, $1710-1800$ m, 8.XII.1989 Härkönen 10113. Zaïre. Buyck (1993b).

Observations. In Africa this is probably the most cited and misunderstood name for Russula. Heim (1938a, b) described many varieties and forms for this species, some of them having been given species status by Buyck (1988, 1990a, b). References in the literature may mean almost any annulate Russula. The loss of the type material makes it very difficult to define this species exactly. $R$. annulata has also been reported by Pegler (1977) from the East Usambara Mountains. 

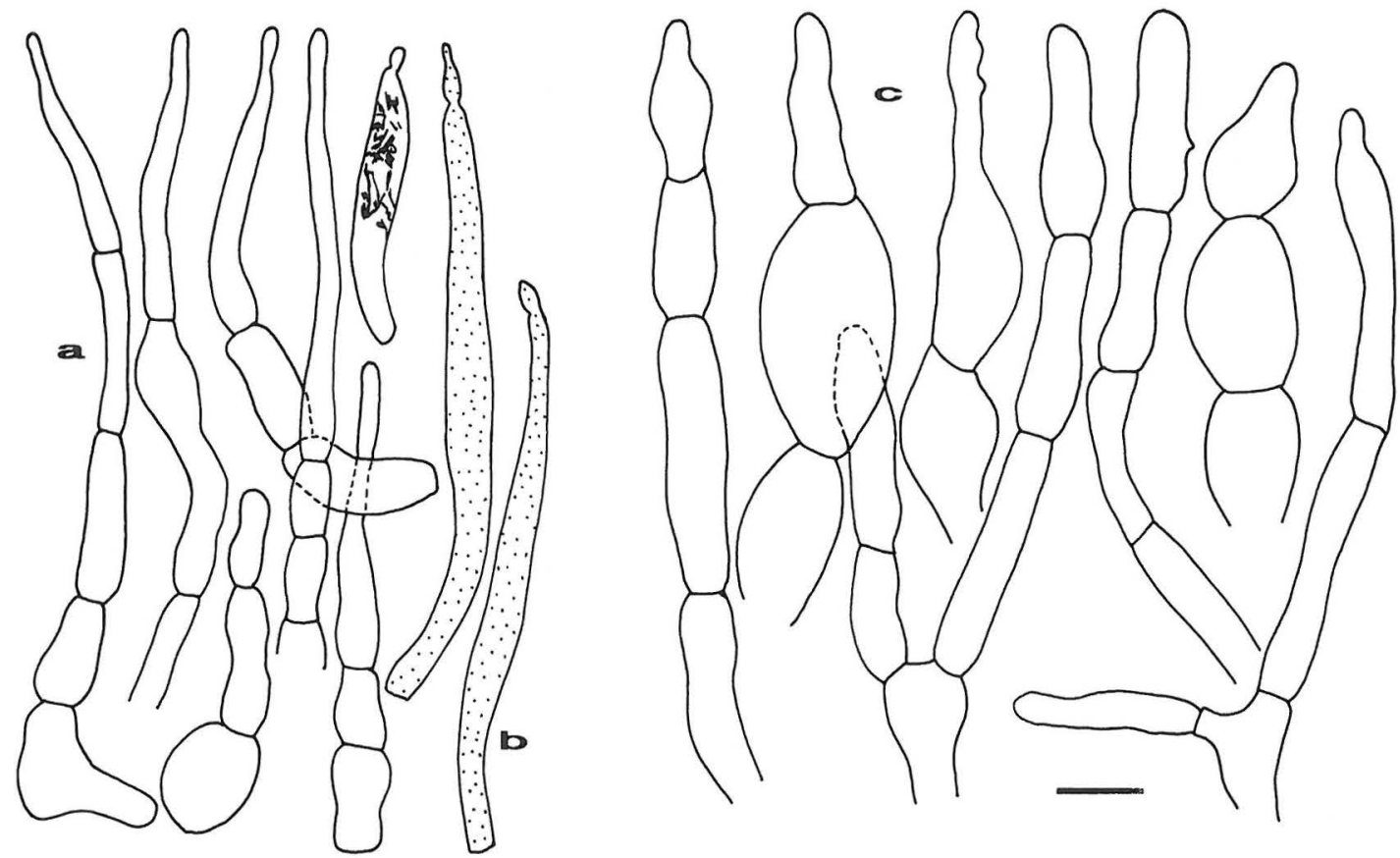

Fig. 7a-c. - a, b. Russula albofloccosa (1078), c. R. echinosperma (913). - a: hyphal extremities of pileus suprapellis, b: dermatocystidia of pileus suprapellis, $\mathrm{c}$ : hyphal extremities of pileus suprapellis. $\mathrm{Bar}=10 \mu \mathrm{m}$.

5. Russula cellulata Buyck, Bull. Jard. Bot. Nat. Belg. 59:245 (1989) — Figs. 9, 35

Description. Buyck (1993b).

Vernacular names. Utyelele (Nyamwezi).

Edibility. Edible (Nyamwezi).

Ecology. Woodland.

Likely hosts. Burundi. Brachystegia microphylla (Buyck, unpubl.). Tanzania. Probably Brachystegia.

Material examined: Tanzania. Western Prov.: Tabora Distr., $20 \mathrm{~km} \mathrm{~W}$ of Tabora, Lulanguru (05 $32 \mathrm{BA}$ ), on soil in woodland with Brachystegia, Terminalia, Combretum, Dichrostachys, Annona, Vitex, Markhamia, 1100 m, 14.XII.1991 Saarimäki et al. 1105a. Zaïre, Burundi. Buyck (1993b). Zambia, Malawi. Buyck (unpubl.).

Observations. A firm and common woodland species probably with a Zambesian distribution, occurring singly or in scattered groups. It is recognized in the field by the yellowish to greyish brown pileus disrupting radially but characteristically also in a concentric mode from the margin towards the center. Another specific character is the ferrugineous pileipellis-like covering of the stipe base which typically breaks up in horizontal bands or polygonal scales. The latter feature was very prominently present in the Tanzanian collection, but can be absent or indistinct as in the type collection (see Buyck 1993b). Several specimens collected in Burundi showed a very pronounced greying context. There is no particular taste or smell. The most typical feature is the cellular aspect of the pileus, which forms a very dense layer in the pileus centre and becomes gradually less dense and composed of larger cells towards the margin. Brown pigmented hyphal extremities are emerging locally from the cellular layer. The pileipellis and the very partially reticulated spores showing an inamyloid suprahilar spot (plage) are the most reliable features in distinguishing $R$. cellulata from similar species. Most collections have scattered and very small, slightly emergent, capitulate dermatocystidia, which are best observed outside the very pileus center as the clavate extremities of the center are much smaller and densely packed into a trichoderm to hymeniderm-structure.

$R$. cellulata is in the field easily confused with a number of other species which occur in the same habitat, often growing side by side with $R$. 
cellulata. R. immaculata (Beeli) Dennis var. mamillata Buyck (subsect. Mamillatinae Buyck) shares a similar stipe base and a pronounced greying context, but has a yellowish-brown pileus and spores with an amyloid plage and completer reticulum, as well as large cylindrical, obtuse pileocystidia which do not protrude into the dense trichoderm but stay confined to the subpellis.

$R$. liberiensis Singer, which is discussed below, can also be confused with $R$. cellulata.

$R$. schizoderma Pat. (subsect. Virescentinae Singer) might also be similar, but its type (PC) was not found. Morris (1987) illustrated and discussed a marketed mushroom in Malawi which Pegler identified for him as $R$. schizoderma. The aquarel represents almost certainly $R$. cellulata, but it is possible that more than one of the abovementioned species are referred to by the same vernacular name.

6. Russula ciliata Buyck, Bull. Jard. Bot. Nat. Belg. 57:387 (1987) — Figs. 5, 20

Description. Buyck (1993b).

Vernacular names. Utyelele (Nyamwezi), Bunitelele (Sumbwa).

Edibility. Edible (Nyamwezi, Sumbwa).

Ecology. Woodland.

Likely hosts. Burundi. Brachystegia microphylla (Buyck, unpubl.). Zambia. Julbernardia paniculata, Brachystegia allenii, Brachystegia
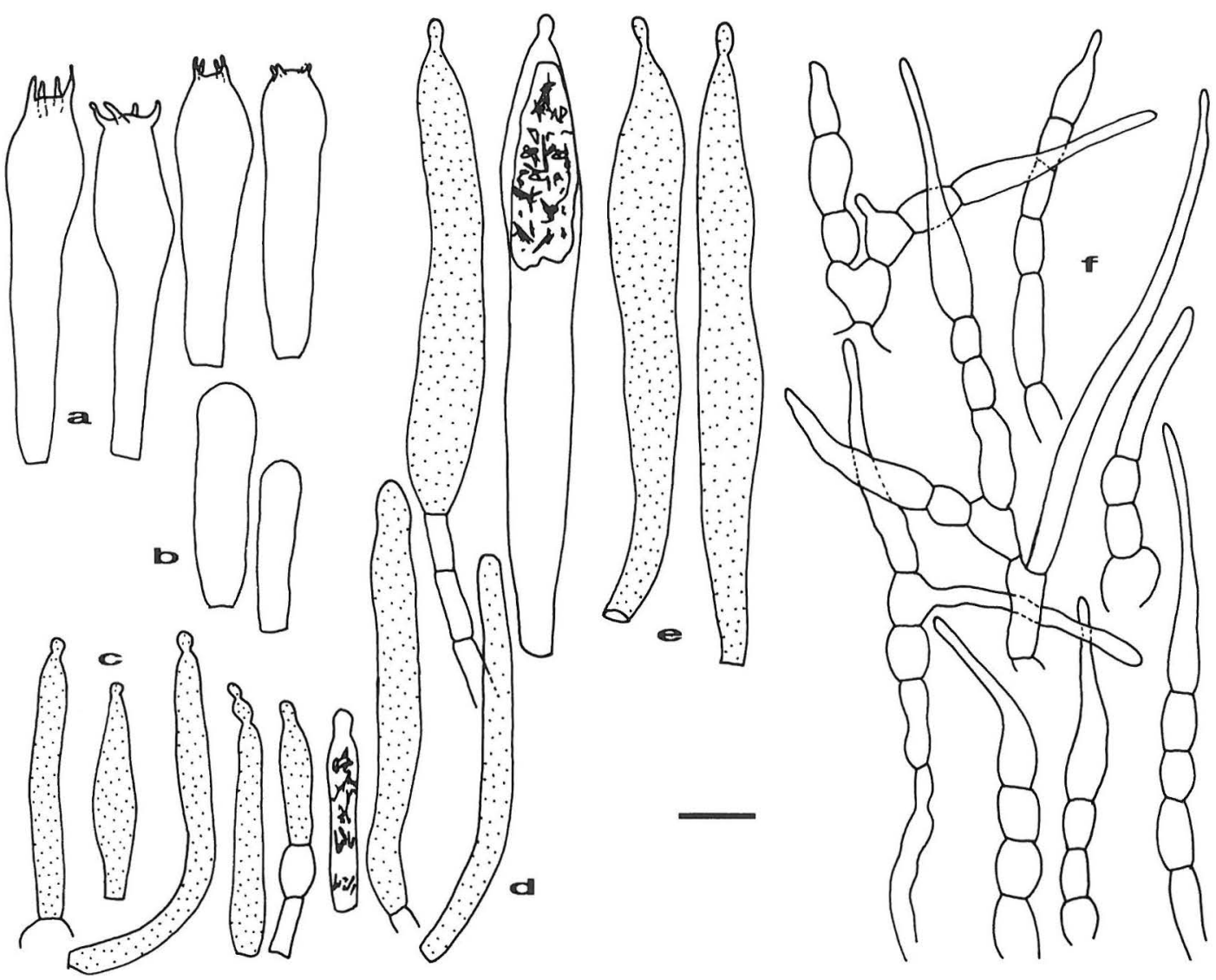

Fig. 8a-f. Russula annulata s.l. (10113). - a: basidia, b: basidiola, c: dermatocystidia of suprapellis of pileus center, d: dermatocystidia of subpellis of pileus center, e: hymenial cystidia, $\mathrm{f}$ : hyphal extremities of pileus suprapellis. $\mathrm{Bar}=10 \mu \mathrm{m}$. 
boehmii, Pericopsis angolensis, Pseudolachnostylis maprouneifolia (Buyck, unpubl.).

Material examined: Tanzania. Western Prov.: Kahama Distr., $30 \mathrm{~km}$ W of Kahama, Wendele, Forest Reserve (03 $32 \mathrm{CB}$ ), on soil in Brachystegia-Combretum woodland, 1200 m, 9.XII.1991 Saarimäki et al. 1022. Tabora Distr., $20 \mathrm{~km} \mathrm{~W}$ of Tabora, Lulanguru (05 $32 \mathrm{BA}$ ), degraded woodland, $1110 \mathrm{~m}$, 14.XII.1991 Saarimäki et al. 1119. Zaïre. Buyck (1993b). Burundi, Zambia, probably also Malawi. Buyck (unpubl.).

Observations. A very distinct, small and common woodland species probably occurring all over the Zambesian domain, often in large numbers. It is easily recognized by the typical yellow to green colour of the pileus, although collections from Zambia and Burundi (Buyck, unpubl.) sometimes show an orange to wine-red pileus colour, especially towards the margin. When the pileus is dry, the granular-floccose to scurfy covering of the pileus is very prominent, but when moist is hidden by a thick slimy layer.

7. Russula compressa Buyck, Bull. Jard. Bot. Nat. Belg. 59:252 (1989) - Fig. 10

Description. Buyck (1993b).

Vernacular names. Bufutwamvula, Busegese, Dumu ya mzee, Katundu, Mnyitundu (Nyamwezi), Utundule (Safwa), Butundutundu (Sukuma), Nitundu (Sumbwa).

Edibility. Edible (Nyamwezi, Safwa, Sukuma, Sumbwa), inedible (Bena).

Ecology. Woodland.

Likely hosts. Burundi. Brachystegia bussei, B. utilis, B. microphylla (Buyck, unpubl.). Tanzania. Brachystegia or Julbernardia.

Material examined: Tanzania. Southern Highlands Prov.: Mbeya Distr., a few $\mathrm{km}$ E of Mbeya, Ipembe Hill (08 $33 \mathrm{CD}$ ), on soil in degraded miombo woodland with Uapaca, Brachystegia and Parinari, 1760 m, 28.III.1991 Saarimäki et al. 751. Lake Prov.: Mwanza Distr., Buharahara, a few $\mathrm{km} \mathrm{W}$ of Geita (02 $32 \mathrm{CD}$ ), on soil in miombo woodland with Brachystegia, Julbernardia, Combretum, Albizia, 1250 m, 5.XII.1991 Saarimäki et al. 1012. Western Prov.: Kahama Distr., $30 \mathrm{~km}$ W of Kahama, Wendele, Forest Reserve, on soil in BrachystegiaCombretum woodland, 1200 m, 9.XII.1991 Saarimäki et al. 1024; $45 \mathrm{~km} \mathrm{SW}$ of Kahama, Mpunze, Forest Reserve, on soil in woodland, $1150 \mathrm{~m}, 10$. XII.1991 Saarimäki et al. 1038. Tabora Distr., $10 \mathrm{~km} \mathrm{~S}$ of Tabora, Kipalapala (05 32 BB), on soil in miombo woodland, $1200 \mathrm{~m}, 12 . X I I .1991$ Saarimäki et al. 1066, 1068; $20 \mathrm{~km} \mathrm{~W}$ of Tabora, Lulanguru (05 $32 \mathrm{BA}$ ), in degraded woodland, $1100 \mathrm{~m}$, 14.XII.1991 Saarimäki et al. 1120. Burundi, Zaïre. Buyck (1993b). Zambia. Buyck (unpubl.).
Observations. A very common red-capped Russula with yellowing context usually occurring in scattered groups all over the Zambesian miombo area. Saarimäki et al. 1066 was the only collection resembling the type in its fishy smell.

$R$. compressa differs in the field from the many other red-capped Russulae either by its larger size, yellowing (not greying) context or by the absence of red colour in the stipe. R. compres$s a$ was characterized (Buyck 1993b) by the low, irregular and broadly obtuse spore ornaments opposing it to the very similar but apparently rare $R$. sejuncta Buyck, which has sharp, conical and \pm regular ornaments (Buyck 1993b). The microscopic features of pileipellis are also rather variable (see Fig. 10): unicellular clavate to multicellular and subcylindrical pileocystidia, many to almost no extremities surpassing the general level of the trichoderm and these extremities composed of either short or of long cells.

8. Russula congoana Patouillard, Bull. Soc. Mycol. France 30:336 (1914) — Figs. 10, 19

Descriptions. Buyck (1993b), Pegler (1977).

Vernacular names. Butundutundu (Sukuma), Katundu, Mnyitundu (Nyamwezi).

Edibility. Edible (Nyamwezi, Sukuma).

Ecology. Woodland.

Likely hosts. Burundi. Brachystegia microphylla, B. bussei, B. spiciformis. Zambia. Marquesia macroura, Brachystegia boehmii, $B$. spiciformis (Buyck, unpubl.).

Material examined: Tanzania. Lake Prov.: Mwanza Distr., Buharahara, a few km W of Geita (02 32 CD), on soil in miombo woodland with Brachystegia, Julbernardia, Combretum, Albizia, 1250 m, 5.XII.1991 Saarimäki et al. 1011, 1013. Western Prov.: Kahama Distr., 45 km SW of Kahama, Mpunze, Forest Reserve (03 $32 \mathrm{CD}$ ), on soil in woodland, $1150 \mathrm{~m}, 10 . \mathrm{XII} .1991$ Saarimäki et al. 1040. Burundi, Congo, Zaïre. Buyck (1993b). Zambia. Buyck (unpubl.).

Observations. A common, widespread and small woodland species, which is easily recognized because of the red colour of both stipe and pileus. It was also reported from Tanzania by Pegler (1977). It is very close to $R$. bururiensis Buyck, which differs mainly by its larger size and by the smaller and less ornamented spores (see Buyck 1993b). 

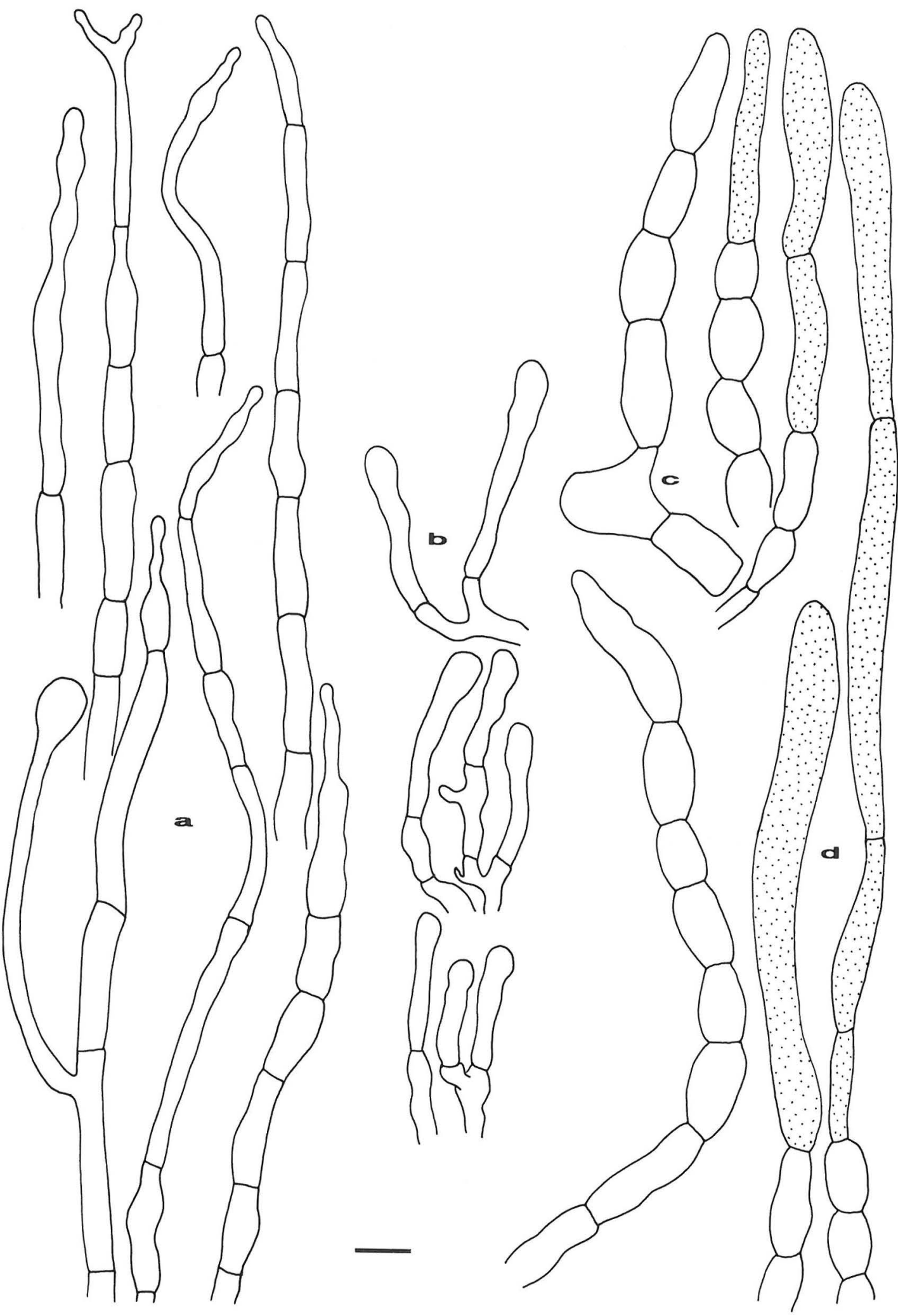
9. Russula echinosperma Heim \& Gilles apud Heim, Rev. Mycol. 36:130 (1971) — Figs. 7, 18

Descriptions. Buyck (1993b), Heim (1971).

Vernacular names. Unknown.

Edibility. Unknown.

Ecology. Woodland.

Likely hosts. Unknown.

Material examined: Tanzania. Tanga Prov.: Lushoto Distr., W Usambara Mts, Mazumbai (04 38 DC), in the surroundings of the village, lower montane forest, 1400 1500 m, 18.IV.1991 Saarimäki et al. 913. Gabon, Zaïre. Buyck (1993b).

Observations. This is only the fifth collection for this species, which was first described from Gabon and is apparently a typical rain forest species. The second author $(\mathrm{BB})$ has never found it in miombo collections from Zaïre, Zambia, Burundi or Malawi. The type (PC) is lost, but the identification is based on comparison with a specimen which was also collected by Gilles in Gabon and labelled by Heim as R. echinosperma (see Buyck 1992).

The three species presently placed in subsection Echinospermatinae are easily recognized under the microscope by the voluminous extremities of the hyphae and the isolated, acute ornaments of the spores which lack an amyloid plage, and the absence of dermatocystidia. The composition of the pileipellis is reminiscent of subsection Olivaceinae Singer sensu Romagnesi (1967), from which subsection Echinospermatinae differs mainly by the pale spore deposit (probably white) and the absence of the typical phenol reaction. $R$. echinosperma is separated from both other Echinospermatinae by the overall reddish-violet colour of the pileus, the very long spines on the spores and, from $R$. acriuscula, also by the mild taste.

Although placed provisionally in section Heterophyllae Fr. (Buyck 1993b), this subsection might be better placed in section Crassotunicatae.
10. Russula heimii Singer, Ann. Mycol. 40:73 (1942) - Figs. 11, 23

$R$. velutipes Heim, Candollea 7:387 (1938) non Velenovsky (1920).

Descriptions. Buyck (1993b), Heim (1938a). Vernacular names. Shimbwoga (Safwa). Edibility. Edible (Safwa), inedible (Bena). Ecology. Woodland.

Likely hosts. Brachystegia or Uapaca.

Material examined: Tanzania. Southern Highlands Prov.: Mbeya Distr., a few km E of Mbeya, Ipembe Hill, on soil in degraded miombo woodland with Uapaca, Brachystegia and Parinari, $1600 \mathrm{~m}, 28$. III.1991 Saarimäki et al. 745. Madagascar. Heim (1938a).

Observations. This is the second find for this species, originally described from Madagascar, and known only from the type (PC, Heim F76). The Tanzanian specimen matches the type very well, both macroscopically (orange-brown pileus centre, paler towards the margin, cream lamellae, white stipe with profuse white mycelium, pinkish turning flesh with distinct odour and slowly acrid taste) and microscopically. A modern description was provided by Buyck (1989e, 1992: fig. 213). A typical microscopic feature appears to be the very long, slender nature of all elements: basidia (53-)60-75 x 7-10 $\mu \mathrm{m}$, cystidia up to $150 \mu \mathrm{m}$ long but only $6-8 \mu \mathrm{m}$ in diam, elements of the pileipellis only $3-5 \mu \mathrm{m}$ in diam. The cystidial elements hardly react with sulfovanilline.

11. Russula hiemisilvae Buyck, sp. nov. - Figs. 12,21

Pileus fragilis, 50-60 mm latus, planusconvexus; margine involutus, fortiter striatus; pellis cinereo-violacea, secernens. Lamellae adnatae, cremeae, confertae, usque ad $4 \mathrm{~mm}$ latae, angustae; acies concolora, integra. Stipes $50-55 \times 10 \mathrm{~mm}$, subcylindratus, attenuatus in basi extrema, albus vel leviter violaceo tinctus,

Fig. 9a-d.- a. Russula liberiensis (755), b. R. cellulata (1105a), c, d. R. sesenagula (408). - a-c: hyphal extremities of pileus suprapellis, d: dermatocystidia of pileus suprapellis. Bar $10=\mu \mathrm{m}$. 
glabrus, cavus in vetere; annulo libri angusto praeditus. Caro alba, inodora, mitis. Sporae in cumulo colore ignotae.

Sporae ellipsoideae, (8.4-)8.84-9.18-9.51(9.7) $\times(7.2-) 7.42-\underline{7.72}-8.03(-8.4) \mu \mathrm{m}(\mathrm{Q}=$ $(1.13-) \underline{1.19}(-1.27))$, moderate dense reticulatae, ornamentis conicis obtusis in cristis angustis confluentibus vel distincte interconnectis valde amyloideis usque ad $1.5 \mu \mathrm{m}$ altis ornatae; macula suprahilaris distincta sed inamyloidea. Basidia 54-66 x 12-14 $\mu \mathrm{m}$, pedicellato-clavata, tetraspora. Cystidia dispersa, $65-80 \times 10-14 \mu \mathrm{m}$, paulum emergentia, clavata vel fusiformia, generaliter appendiculato-capitata, tenuitunicata; contentu distincta, in SV rufescente repleta. Cellulae marginales basidioliformes, clavatae ad fusiformes, obtusae, parvae. Pileipellis orthochromatica in azureo cresylico; subpellis hyphis tenuibus gelatinosis efformata; suprapellis extremitatibus brevibus dense septatis ramosis, ex cellula basale inflata ac cellula terminale generaliter sursum attenuata ac 1-2 cellulis plus minusve ellipsoideis interpositis compositis efformata; pileocystidia $20-35(-45) \times 5-6(-8)$ $\mu \mathrm{m}$, terminalia, fusiformia vel lageniformia, capitulata. Stipitipellis minus gelatinosa.

Holotypus: Tanzania. Western Prov.: Kahama Distr., $30 \mathrm{~km} \mathrm{~W}$ of Kahama, Wendele, Forest Reserve (03 $32 \mathrm{CB})$, on soil in Brachystegia-Combretum woodland, $1200 \mathrm{~m}$, 9.XII.1991 Saarimäki et al. $1028(\mathrm{H})$.

Pileus $50-60 \mathrm{~mm}$ in diam, convex to flat, at first involuted; margin broadly striate; pellis greyish violet, distinctly peeling. Lamellae adnexed, cream, crowded, up to $4 \mathrm{~mm}$ broad, fairly thin; edge smooth, concolorous. Stipe 50$55 \times 10 \mathrm{~mm}$, equal, tapering at base, white or with a faint violet tone, smooth, becoming hollow with age. Ring narrow, free around the stipe. Flesh white, without smell; taste mild. Spore print not obtained.

Spores ellipsoid, (8.4-)8.84-9.18-9.51(-9.7) $\mathrm{x}$ (7.2-)7.42-7.72-8.03(-8.4) $\mu \mathrm{m}(\mathrm{Q}=(1.13-) \underline{1.19}$ (1.27)), rather densely ornamented with conical, obtuse elements which are up to $1.5 \mu \mathrm{m}$ high, strongly amyloid, distinctly interconnected or united into narrow ridges, completely re-ticulate; suprahilar spot distinct but not amyloid. Basidia 54-66 x 12-14 $\mu \mathrm{m}$, clavate to pedicellate, 4-spored. Cystidia dispersed, 65-80 x 10-14 $\mu \mathrm{m}$, slightly emergent, clavate to fusiform, usually appendiculate or capitulate, thin-walled; contents distinct, with almost negative reaction (reddening) in sulfovanillin. Marginal cells clavate to fusoid, basidiole-like, obtuse, distinctly smaller than the basidia. Pileipellis orthochromatic in cresyl blue, a gelatinized subpellis composed of slender hyphae, $2-4 \mu \mathrm{m}$ in diam; suprapellis composed of short and densely septate extremities formed of one or two ellipsoid cells carying a longer tapering terminal cell and supported by a larger branching cell at the base; terminal cell slightly restricted below the apex and more or less capitate; pileocystidia 20 $35(-45) \times 5-6(-8) \mu \mathrm{m}$, terminal, fusoid to lageniform, capitulate. Stipitipellis more or less similar to the pileipellis but less gelatinized.

Vernacular names. Nitundu (Sumbwa).

Edibility. Edible (Sumbwa).

Ecology. Woodland.

Likely hosts. Burundi. Brachystegia microphylla (Buyck, unpubl.). Tanzania. Probably Brachystegia.

Material examined: Tanzania. Western Prov.: holotype. Burundi, Zambia. Buyck (unpubl.). Perhaps Senegal, Zaïre. Buyck (1993b).

Observations. A common annulate species in miombo vegetation, usually gregarious with two or three fruit bodies. It is well characterized by its large dimensions, typical pileus colour and ellipsoid spores (most other annulate species have nearly globose spores with more pronounced ornamentation).

Very similar collections have been described from Shaba in Zairre, and were attributed (Buyck $1993 b$ ) to $R$. roseoalba Buyck sensu lato. These differ mainly from the Tanzanian collection in the slightly different spore ornamentation which shows more individualised verrucae. It might be a subspecies of $R$. hiemisilvae.

Fig. 10a-h. - a, b. Russula congoana (1011), c-h. R. compressa c, d: 1038, e:1066, f: 1068, g: 1120, h: 1012. Elements of pileus suprapellis: dermatocystidia with schematic indication of contents, ordinary hyphal extremities represented as empty. Bar $10=\mu \mathrm{m}$. 


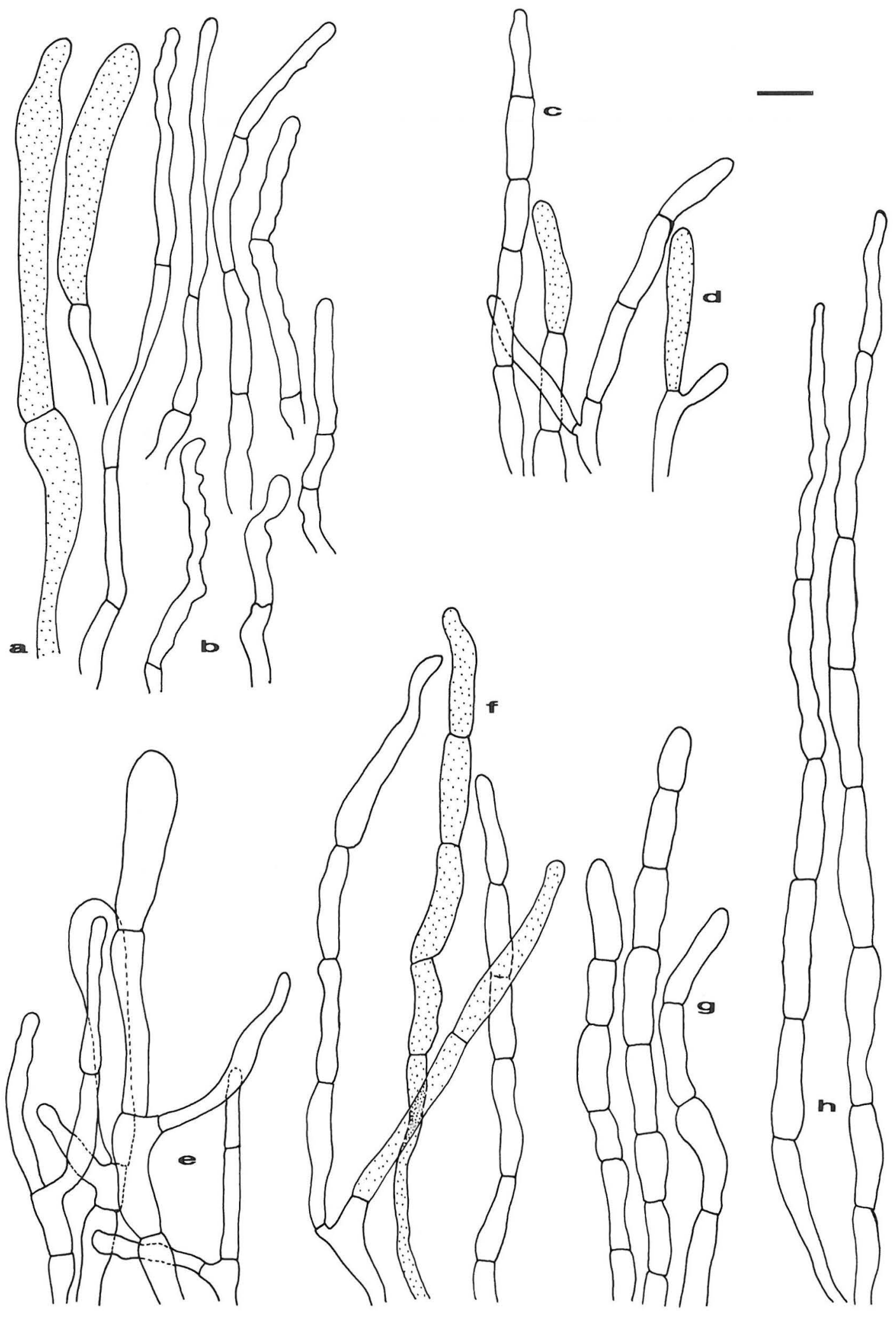



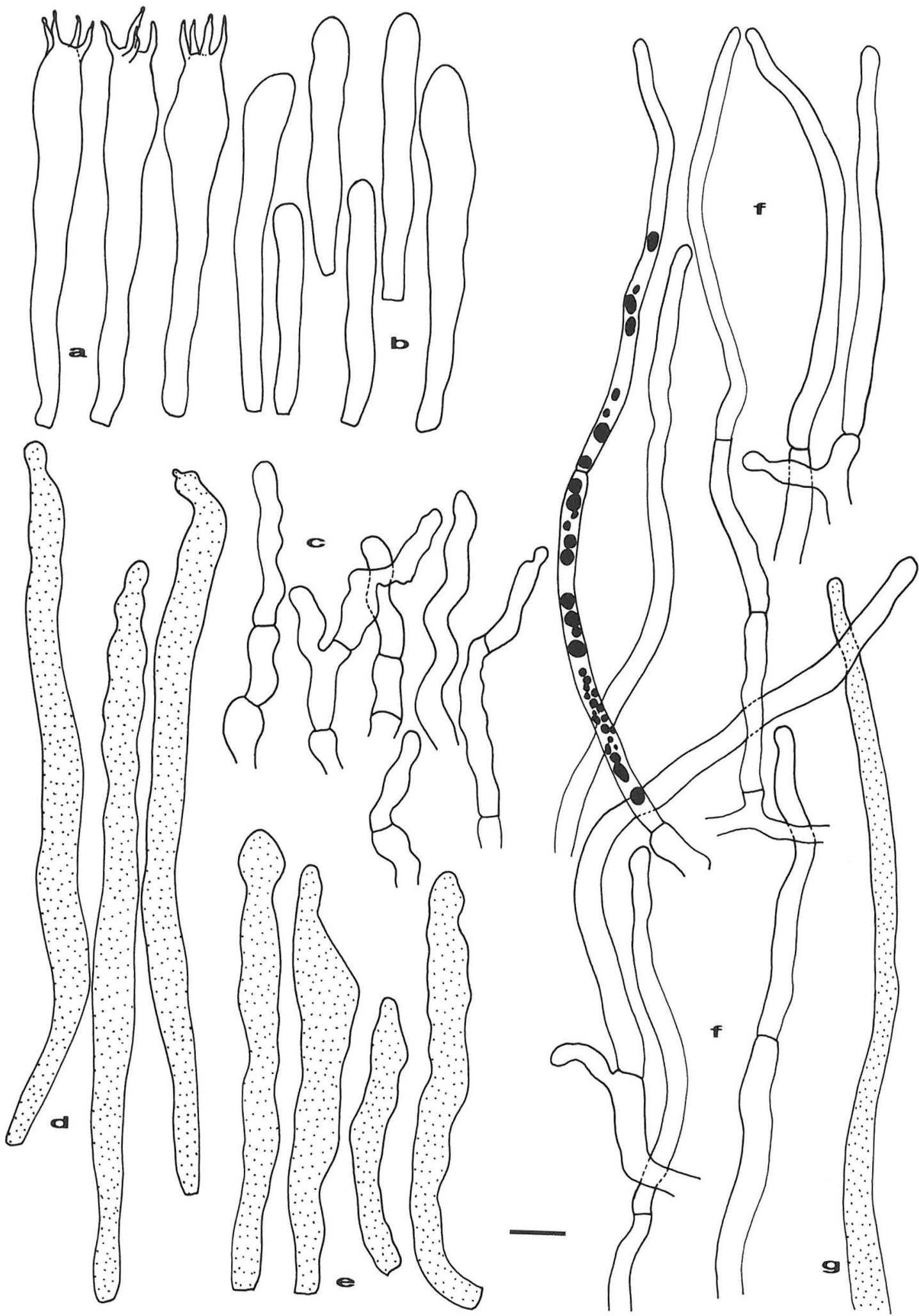
12. Russula liberiensis Singer, Pap. Michigan Acad. Sci. 32:112 (1946) - Figs. 9, 23

Description. Buyck (1993b).

Vernacular names. Shimbwoga? (Safwa).

Edibility. Edible (Bena, Safwa), inedible (Nyamwezi).

Ecology. Woodland.

Likely hosts. Burundi. Brachystegia microphylla (Buyck, unpubl.). Tanzania. Probably Uapaca or Brachystegia.

Material examined: Tanzania. Southern Highlands Prov.: Mbeya Distr., a few $\mathrm{km} \mathrm{E}$ of Mbeya, Ipembe Hill ( 08 $33 \mathrm{CD}$ ), on soil in degraded miombo with Uapaca, Brachystegia and Parinari, $1760 \mathrm{~m}, 28 . I I I .1991$ Saarimäki et al. 755. Western Prov.: Tabora Distr., $20 \mathrm{~km} \mathrm{~W}$ of Tabora, Lulanguru (05 32 BA), degraded woodland, 1100 m, 14.XII.1991 Saarimäki et al. 1118. Liberia. Buyck (1993b). Burundi, Zambia, Zaïre. Buyck (unpubl.).

Observations. A rare woodland species resembling $R$. cellulata by the colour of the pileus and the forked lamellae. It differs from the latter in the composition of the pileipellis, which is not epitheloid and has a smooth to finely areolate aspect, and in the larger variation of the spore ornamentation.

Saarimäki et al. 1118 is a somewhat aberrant collection because of the extremely tortuous, irregular form of the hyphal extremities in the suprapellis and the abundance of oleiferous hyphae. The spores, however, fit the description as well as fitting most of the macroscopic observations that have been made.

13. Russula pectinatoides Peck, Rep. New York State Bot.: 90, pl. 105, figs. 6-10 (1906)

Description. Romagnesi (1967).

Vernacular names. Unknown.

Edibility. Unknown.

Likely hosts. Accompanying introduced $P i$ nus in Africa.

Material examined: Tanzania. Northern Prov: Arusha Distr., Mt Meru W slope, NE of Olmotonyi, close to Laikinoi, Training Forest of the Sokoine Univ. of Agriculture (03 $36 \mathrm{BC}$ ), Pinus patula plantation, $1950 \mathrm{~m}$, 15.XII.1989 Saarimäki 478, 480.

Observations. An introduced Russula, which is restricted to Pinus plantations in Africa.
14. Russula phaeocephala Buyck, Bull. Jard. Bot. Nat. Belg. 59:246 (1989) — Figs. 13, 22

Description. Buyck (1993b).

Vernacular names. Mashikoba, Usihwe (Nyamwezi).

Edibility. Some consider edible, some inedible (Nyamwezi).

Ecology. Woodland.

Likely hosts. Tanzania. Probably Brachystegia or Julbernardia.

Material examined: Tanzania. Lake Prov.: Mwanza Distr., Buharahara, a few km W of Geita (02 32 CD), on soil in miombo woodland with Brachystegia, Julbernardia, Combretum and Albizia, 1250 m, 5.XII.1991 Saarimäki et al. 1007a. Burundi. Buyck (1993b).

Observations. This is only the second record for this species. It agrees almost completely with the type in its macro- and microscopic features and its woodland habitat (the type was found in degraded woodland vegetation). The Tanzanian collection of $R$. phaeocephala has a distinct smell which resembles the smell of Lactarius rufus.

The capitulate pileocystidia are very rare and easily overlooked because of their poor contents and small dimensions.

Other species of subsection Nigricantes with mild taste and similar spore ornamentation are $R$. areolata Buyck, which occurs also in woodland vegetation but has much more widely spaced and also thicker lamellae and a different aspect of the pileus (cf. Buyck 1993b: pl. 58/1), and $R$. afronigricans Buyck (cf. Buyck 1993b: pl. 59/1), which has smaller spores and was found in equatorial rain forest in Zaïre.

15. Russula sesenagula Beeli, Bull. Soc. Roy. Bot. Belg. 60:166 (1928) — Fig. 9

Description. Buyck (1993b).

Vernacular names. Unknown.

Edibility. Unknown.

Ecology. Humid equatorial to lower montane forest.

Likely hosts. Zaïre. Probably Gilbertiodendron dewevrei (Buyck 1989).

Material examined: Tanzania. Tanga Prov.: Lushoto Distr., W Usambara Mts, Mazumbai Forest Reserve border

Fig. 11a-g. Russula heimii (745). - a: basidia, b: basidiola, c: marginal cells of lamella edge, d: pleurocystidia, e: cheilocystidia, $\mathrm{f}$ : hyphal extremities of pileus suprapellis with indication of brown necropigment in one element, $g$ : dermatocystidium of pileus suprapellis. Bar $=10 \mu \mathrm{m}$. 
(04 $38 \mathrm{DC}$ ), in moist lower montane forest, $1600 \mathrm{~m}$, 7.XII.1989 Saarimäki 408. Burundi, Zambia. For $R$. sesenagula s.l. (Buyck, unpubl.). Zaïre. Buyck (1993b).

Observations. This species was conceived sensu lato (Buyck 1993b) because apparently a large number of \pm reddish tropical Russula species have more or less the same composition of the pileipellis and spore ornamentation. The Tanzanian collection agrees in every respect with $R$. sesenagula sensu stricto, having almost identical microscopic and macroscopic (see key) features as the type (see Buyck 1993b), the whitish lamellae of the type forming the only notable exception; but this might be due to immaturity.

$R$. sesenagula sensu stricto differs from the other species of subsection Luteomaculatinae by the fact that the suprapellis is composed solely of large elements comparable to those that surpass the general level of the suprapellis in the other species (e.g. $R$. compressa). The small and narrow extremities composing the major part of the trichoderm in the other Luteomaculatinae are not present in $R$. sesenagula sensu stricto.

16. Russula subfistulosa Buyck, Bull. Jard. Bot. Nat. Belg. 60:193 (1990) — Figs. 14, 36, 37

Description. Buyck (1993b).

Vernacular names. Unknown.

Edibility. Unknown.

Ecology. Humid forest to woodland.

Likely hosts. Burundi. Brachystegia spiciformis, B. bussei, B. utilis, B. microphylla (Buyck, unpubl.).

Material examined: Tanzania. Tanga Prov.: Lushoto Distr., W Usambara Mts, Mazumbai, N of the Mazumbai Forest Reserve border and Kambi Falls, Kwamshundi, in lower montane forest, 1 710-1 800 m, 8.XII.1989 Härkönen 10121. Burundi, Zaïre. Buyck (1993b). Zambia. Buyck (unpubl.).
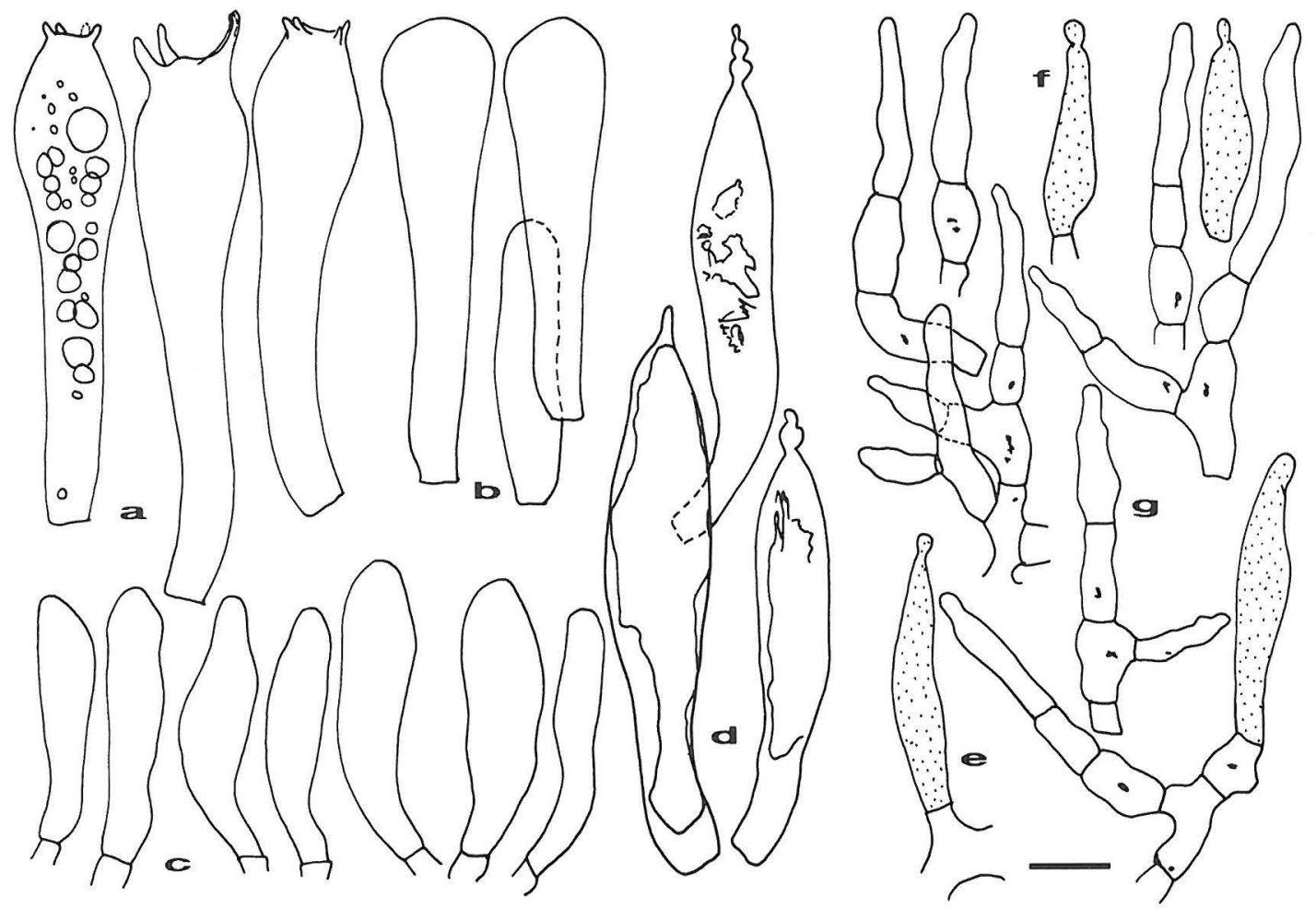

Fig. 12a-g. Russula hiemisilvae (type). - a: basidia, b: basidiola, c: marginal cells of lamella edge, d: hymenial cystidia, e, f: dermatocystidia of pileus suprapellis, $\mathrm{g}$ : hyphal extremities of pileus suprapellis. Bar $=10 \mu \mathrm{m}$. 

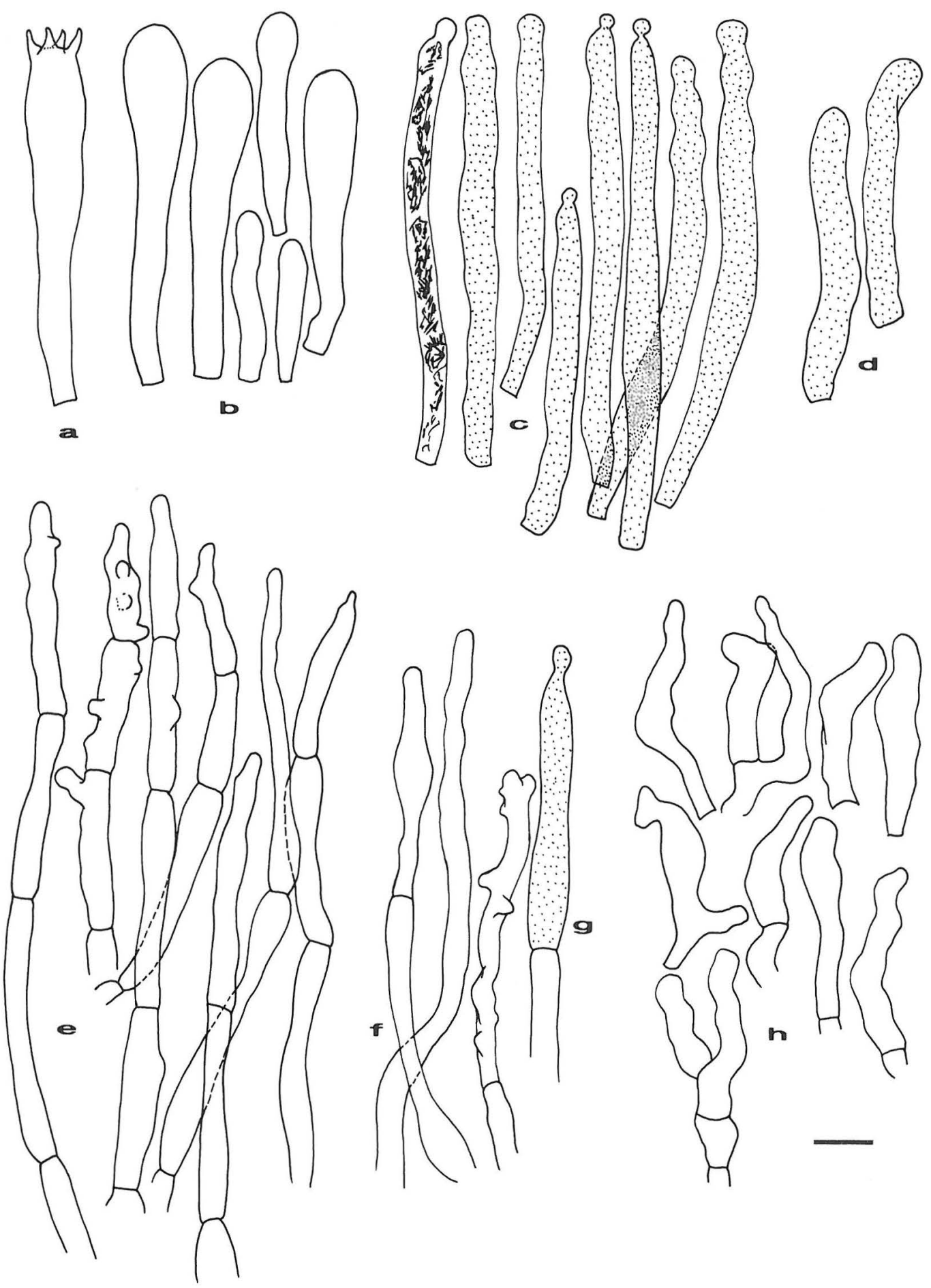

Fig. 13a-h. Russula phaeocephala (1007a). — a: basidia, b: basidiola, c: pleurocystidia, d: cheilocystidia, e, f: hyphal extremities of pileus center, g: dermatocystidia of pileus suprapellis, h: marginal cells of lamella edge. Bar $=10 \mu \mathrm{m}$. 
Observations. R. subfistulosa often occurs in large groups, both in the rain forest and in the woodland area. Different varieties have been recognized - most of them provisionally (Buyck 1993b). Var. apsila, known only from the type, was distinguished (Buyck 1990) on the basis of the denser ornamentation of the spores, the darker colour of the basidioma and the different ecology. This specimen agrees in the two latter features but has the spores of the var. subfistulosa. Clearly, study of additional collections is needed to define the value of the different varieties.

$R$. subfistulosa is characterized by the hot taste, the very crowded and narrow lamellae and lamellulae and the identical covering on stipe and pileus. In the field it is sometimes mistaken for some Tricholomataceae.

17. Russula sublaevis (Buyck) Buyck, stat. nov. - Figs. 15, 25, 33

Basionym: $R$. roseoviolacea Buyck forma sublaevis Buyck, Bull. Jard. Bot. Nat. Belg. 60:204 (1990).

Description. Buyck (1993b).

Vernacular names. Utyelele (Nyamwezi).

Edibility. Edible (Nyamwezi).

Ecology. Woodland.

Likely hosts. Tanzania. Probably Brachystegia.

Material examined: Tanzania. Western Prov.: Tabora Distr., $20 \mathrm{~km} \mathrm{~W}$ of Tabora, Lulanguru (05 $32 \mathrm{BA}$ ), on soil in woodland with Brachystegia, Terminalia, Combretum, Dichrostachys, Annona, Vitex, Markhamia, $1100 \mathrm{~m}$, 14.XII.1991 Saarimäki et al. 1105b. Zaïre. Buyck (1993b): holotype described from Lubumbashi region. Malawi. Buyck (unpubl.).

Observations. Already described by Buyck from a single collection (with unsufficient field notes) from Zairre as $R$. roseoviolacea s.l. forma sublaevis Buyck. This collection, as well as a similar specimen collected by B. Morris in Malawi (Morris, unpubl.), shows that it definitely deserves to be ranked as a species. Its most distinctive features are a moderately large, yellow pileus, white lamellae and stipe and absolutely mild and odourless flesh. $R$. sublaevis is perhaps intermediate between $R$. roseoviolacea
Buyck (see Buyck 1993b) and R. albofloccosa Buyck, which have quite similar microscopic features. $R$. roseoviolacea and $R$. albofloccosa have both a pileus with prominent pellicules. All three species have reticulately ornamented spores: not dense and with distinct ridges in $R$. roseoviolacea, moderately dense and with more individualised verrucae in $R$. albofloccosa, and very dense to dense ornamentation with very low verrucae in $R$. sublaevis.

18. Russula tanzaniae Buyck, sp. nov. - Figs. $15,24,31$

Pileus parvus, cremeus; pellis non secernens; margo non striatus. Lamellae colore flava tinctae, densissime dispositae $(32 \mathrm{~L} / \mathrm{cm}$ ad marginem). Stipes albus; sapor odorque acres. Caro acris. Sporae in cumulo colore ignotae.

Sporae breviter ellipsoideae, (5.9-)6.23$\underline{6.49}-6.75(-6.9) \times(5.0-) 5.32-\underline{5.60}-5.87(-6.1)$ $\mu \mathrm{m}(\mathrm{Q}=(1.10-) \underline{1.16}(-1.25))$, verrucis parvis vel parvissimis obtusis sejunctis distincte amyloideis ornatae, macula suprahilaris inamyloidea, indistincta. Basidia 35-45 × 7-9 $\mu \mathrm{m}$, tenuia, clavulata, tetraspora. Cystidia valde abundantia, vix emergentia, tenuia, 35-70(-100) × 6-8 $\mu \mathrm{m}$, distinctiora in acie, subcylindrata ad clavata, obtusa vel minute capitata, contentu SV-abundante repleta. Cellulae marginales non differentiatae. Pileipellis hyphis pileocystidiisque laxe intermixtis ambo subhorizontalibus irregularibus sinuosis, 2-6(-10) $\mu \mathrm{m}$ diam., saepe moderate crassotunicatis, orthochromaticis in azureo cresylico, laxe septatis efformata; cellula hypharum terminalis interdum moniliformis vel subapicale irregulariter inflata; pileocystidia contentu ac extremitate distincte capitata hyphis differentiata. Stipitipellis hyphis plus minusve regularibus tenuitunicatis caulocystidiisque numerosis sursum inflatis composita.

Holotypus: Tanzania. Southern Highlands Prov.: Mbeya Distr., Mbozi (09 32 BB), miombo woodland planted with Cupressus, 1650 m, 24.III.1991 Saarimäki et al. $708(\mathrm{H})$.

Pileus small, cream-coloured; pellis not peeling at the margin. Lamellae yellowish, very crowded (32 lamellae + lamellulae/cm at pileus

Fig. 14a-h. - a-f. Russula tenuithrix (type), g-h. R. subfistulosa (1012l). — a: basidia, b: basidiola, c: hymenial cystidia, $\mathrm{d}$ : hyphal extremities of pileus suprapellis, e: hyphal extremities of stipe, f: dermatocystidia of stipe suprapellis, $g$ : dermatocystidia of pileus suprapellis, h: hyphal extremities of pileus suprapellis. Bar $=10 \mu \mathrm{m}$. 

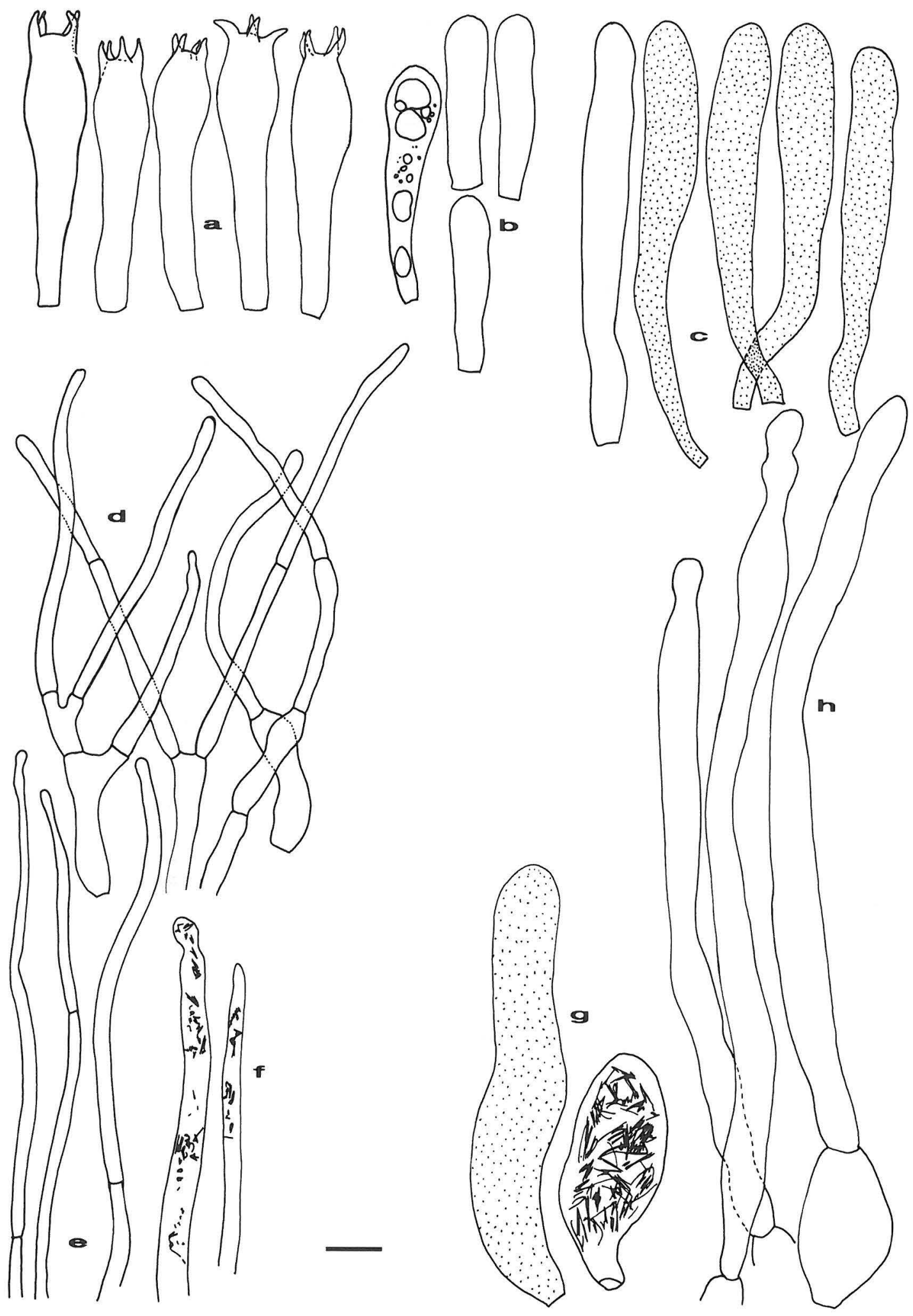
margin). Stipe white. Flesh brittle, with acrid taste and smell. Spore deposit not obtained.

Spores broadly ellipsoid, small, (5.9-)6.236.49-6.75(-6.9) x (5.0-)5.32-5.60-5.87(-6.1) $\mu \mathrm{m}(\mathrm{Q}=(1.10-) \underline{1.16(-1.25))}$, with small to very small, obtuse, low but distinctly amyloid, isolated warts; suprahilar spot indistinct, not amyloid. Basidia 35-45 x 7-9 $\mu \mathrm{m}$, not voluminous, slightly clavate, 4-sterigmate. Cystidia very abundant, hardly emergent, slender, 35-70(-100) x 6-8 $\mu \mathrm{m}$, occupying almost the entire edge and there very obvious, subcylindric to clavate, broadly obtuse to minutely capitate; contents abundant but practically insensitive to SV. Marginal cells not particularly differentiated. Pileipellis a loosely interwoven mat of \pm horizontal hyphae and pileocystidia, of very irregular diam, $2-6(-10) \mu \mathrm{m}$, tortuous and sinuose, with slightly thickened walls (usually 1 $\mu \mathrm{m}$ thick), entirely orthochromatic in cresyl blue, with dispersed septa; terminal cell often moniliform or irregularly inflated at the apex; pileocystidia irregularly cylindrical, of same dimensions as the hyphae, equally septate, usually capitate, with poor to abundant contents, also present in the trama (endocystidia). Stipitipellis showing the same general structure, but composed of more regular, almost cylindrical and more thin-walled elements; caulocystidia even more abundant, relatively large, broadly obtuse and slightly inflated near the apex.

Vernacular names. Unknown.

Edibility. Edible (Nyiha).

Ecology. Woodland.

Likely hosts. Unknown.

Material examined: Tanzania. Southern Highlands Prov.: holotype.

Observations. This is the third African species of subsection Archaeinae. It differs from both the others (see Buyck 1992) especially by the crowded lamellae. R. aucarum Singer, placed by its author in a separate section (Delicoarchaeae Singer), resembles the present species in the irregularly tortuous hyphae of the pellis, but differs by its mild taste and crested spores. Sect. Metachromaticae Singer, based on metachromatic staining of the thick-walled cys- tidia but synonymized by Buyck (1990) with subsect. Cyanoxanthinae Singer because of a similar metachromatic reaction in cresyl blue and the equally elastic lamellae, also has rather closely related micro- and macroscopic features. A typical feature of subsection Archaeinae appears to be the very small spores ornamented with isolated, blunt and minute verrucae.

19. Russula tenuithrix Buyck, sp. nov. - Figs. $14,27,32,34$

Pileus $60 \mathrm{~mm}$ latus, irregulariter convexus, in centro depressus, pelle viridi-grisea, saturate grisea in centro, secernente praeditus, laevis. Lamellae adnatae, usque ad $10 \mathrm{~mm}$ latae, confertae, moderate crassae, flavo-albidae; acies integra, concolora. Stipes $50 \times 15 \mathrm{~mm}$, basim versus leviter attenuatus, saturate griseus. Caro alba, inodora, mitis. Sporae in cumulo colore ignotae.

Sporae ellipsoideae, (7.9-)8.07-8.49-8.91(9.5) $\times(6.2-) 6.39-\underline{6.70}-7.01(-7.2) \mu \mathrm{m}(\mathrm{Q}=$ (1.19-)1.27(-1.34)), verrucis usque ad $0.5 \mu \mathrm{m}$ altis convexis amyloideis dense dispositis plerumque subtile connectis, locale in cristis brevibus confluentibus ornatae, subreticulatae; macula suprahilare indistincta, verruculosa sed inamyloidea. Basidia (38-)40-50 x (9-)10-11 $\mu \mathrm{m}$, tetraspora. Cystidia dispersa, vix emergentia, 50-70(-85) x 8-10(-12) $\mu \mathrm{m}$, generaliter clavata vel subapicale attenuata, moderate tenuitunicata, contentu distincta sed paululum SV+ repleta. Cellulae marginales vix differentiatae. Pileipellis orthochromatica in azureo cresylico; subpellis hyphis tenuibus, 3-4 $\mu \mathrm{m}$ diam., dermatocystidiisque filamentosis, 3-6 $\mu \mathrm{m}$ diam. efformata; suprapellis extremitates ramosae, locale fasciculatae, articulis cylindratis 2-3 $\mu \mathrm{m}$ diam., prope septis vel ramificationibus saepe usque ad $5 \mu \mathrm{m}$ inflatis compositae, cellulis basalibus inflatis pigmento vacuolare brunneo praeditis plus minusve strato pseudoparenchymatice agregatis ortae. Stipitipellis hyphis $2-3 \mu \mathrm{m}$ diam. locale ad 5-7 $\mu \mathrm{m}$ inflatis caulocystidiisque cylindratis obtusis vel capitatis 4-8 $\mu \mathrm{m}$ diam. efformata.

Fig. 15a-j. - a-e. Russula tanzaniae (type), f-j. R. sublaevis stat. nov. (1105b). — a: hymenial cystidia, b: basidia, c: basidiola, d: hyphal extremities of pileus suprapellis, e: dermatocystidia of pileus suprapellis, f: basidia, g: basidiola, h: hymenial cystidia, $\mathrm{i}$ : dermatocystidia of pileus suprapellis, $\mathrm{j}$ : hyphal extremities of pileus suprapellis. Bar $=10 \mu \mathrm{m}$. 


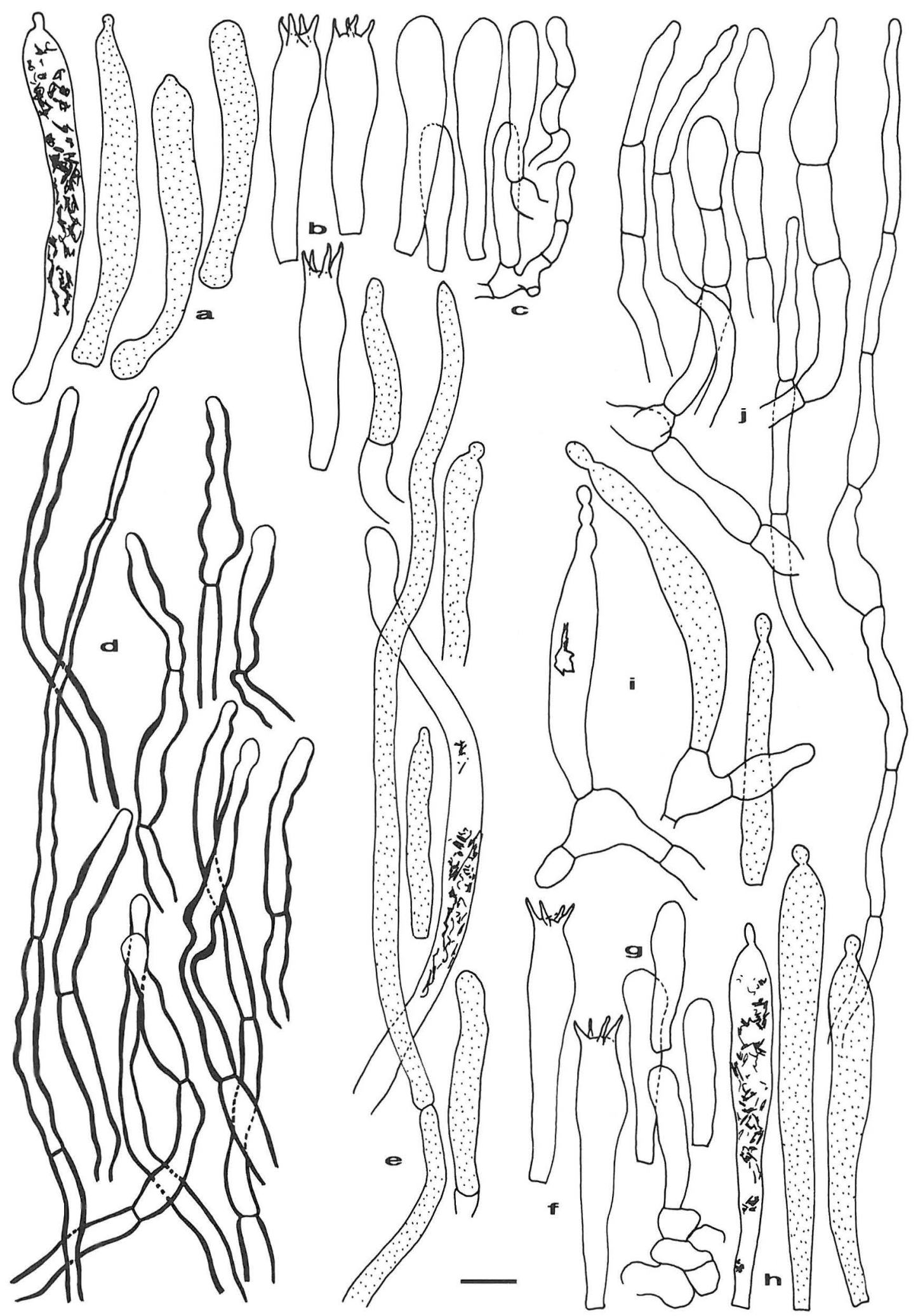


Holotypus: Tanzania. Western Prov.: Tabora Distr., $20 \mathrm{~km} \mathrm{~W}$ of Tabora, Lulanguru (05 $32 \mathrm{BA})$, on soil in degraded woodland with Agave sisalana, Brachystegia, Terminalia, Parinari, Albizia, 1100 m, 14.XII.1991 Saarimäki et al. $1110(\mathrm{H})$.

Pileus $60 \mathrm{~mm}$ in diam, asymmetrically convex, depressed at the center, greenish grey, darker at the center, smooth, peeling. Lamellae adnexed, up to $10 \mathrm{~mm}$ broad, closely arranged, moderately thick, yellowish white; edge smooth, concolorous. Stipe $50 \times 15 \mathrm{~mm}$, slightly narrowing at the base, dull grey. Flesh white, without special smell, mild. Spore deposit not obtained.

Spores ellipsoid, (7.9-)8.07(6.2-)6.39- 6.70-7.01(-7.2) $\mu \mathrm{m}(\mathrm{Q}=(1.19-) 1.27(-$ 1.34)); ornamentation a dense and almost complete reticulum composed of very low (up to $0.5 \mu \mathrm{m}$ ), irregularly convex, delicately connected, amyloid elements, locally confluent in short and narrow ridges; suprahilar spot indistinct, slightly verruculose but not amyloid. Basidia (38-)40-50 x (9-)10-11 $\mu \mathrm{m}, 4$-spored; sterigmata stout, 4-6 $\mu \mathrm{m}$ long. Cystidia dispersed, hardly emergent, $50-70(-85) \times 8-10(-$ 12) $\mu \mathrm{m}$, mostly clavate, sometimes subapically slightly narrowed, with distinct, very weakly $\mathrm{SV}+$ contents and slightly thickened wall. Marginal cells of lamella edge not particularly differentiated. Pileipellis orthochromatic in cresyl blue, composed of narrow hyphae which are 3-4 $\mu \mathrm{m}$ in diam in the subpellis, with dispersed long, slender, cylindrical dermatocystidia measuring 3-6 $\mu \mathrm{m}$ in diam and continuing in the underlying trama; suprapellis a trichoderm composed of ramified cylindrical extremities, locally fasciculated, $2-3 \mu \mathrm{m}$ in diam but sometimes inflated to $5 \mu \mathrm{m}$ at branching sites or near septa, slightly tapering at the top or broadly rounded to subcapitulate, usually containing a diffuse brown pigment, especially in the inflated branching cells; the latter forming a thin, more or less pseudoparenchymatous layer; dermatocystidia in the suprapellis not observed. Stipitipellis composed of hyphae $2-3 \mu \mathrm{m}$ in diam, locally inflated to 5-7 $\mu \mathrm{m}$, caulocystidia 4-6 $\mu \mathrm{m}$ in diam, cylindrical, obtuse to capitate.
Vernacular names. Unknown.

Edibility. Inedible (Nyamwezi).

Ecology. Woodland.

Likely hosts. Malawi, Tanzania. Probably Brachystegia (fide B. Morris for Malawi).

Material examined: Tanzania. Western Prov.: holotype. Malawi. Buyck (unpubl.).

Observations. This species is apparently closely related to $R$. cinerella Pat. (from Madagascar), which has much smoother spores and appendiculate, fusoid cystidia. Both have a greyish green pileus and the same dimensions for basidia and cystidia. Pegler described $R$. cinerella from Tanzania, but this collection had much more prominently warted spores.

20. Russula testacea Buyck, Bull. Jard. Bot. Nat. Belg. 58:475 (1988) - Fig. 16

Description. Buyck (1993b).

Vernacular names. Kansalaghe (Sukuma).

Edibility. Inedible (Sukuma).

Ecology. Woodland.

Likely hosts. Burundi. Brachystegia microphylla. Zambia. Julbernardia paniculata, Brachystegia spiciformis (Buyck, unpubl.).

Material examined: Tanzania. Western Prov.: Kahama Distr., $45 \mathrm{~km}$ SW of Kahama, Mpunze, Forest Reserve (03 $32 \mathrm{CD}$ ), on soil in woodland, $1150 \mathrm{~m}$, 10.XII.1991 Saarimäki et al. 1039, 1043. Zambia, Burundi. Buyck (unpubl.).

Observations. A widespread woodland species occurring singly or in small groups. It is easily recognized by the overall brownish ochraceous colour, the slightly paler lamellae being concolorous with the pileus margin and stipe apex. $R$. testacea is also microscopically well characterized by the features of the spores and composition of the trichodermal pileipellis which has none or not well-differentiated pileocystidia.

The systematic position of this species is doubtful. It could be placed either in sect. Integrae Maire or in sect. Polychromae Maire.

Fig. 16a-f. - a-e. Russula usambarae (type), f. R. testacea (1039). — a: basidia, b: hyphal extremities of pileus center, $\mathrm{c}$ : hyphal extremities of pileus margin, d: hyphal extremities of stipe, e: hymenial cystidia, f: hyphal extremities of pileus suprapellis. Bar $=10 \mu \mathrm{m}$. 

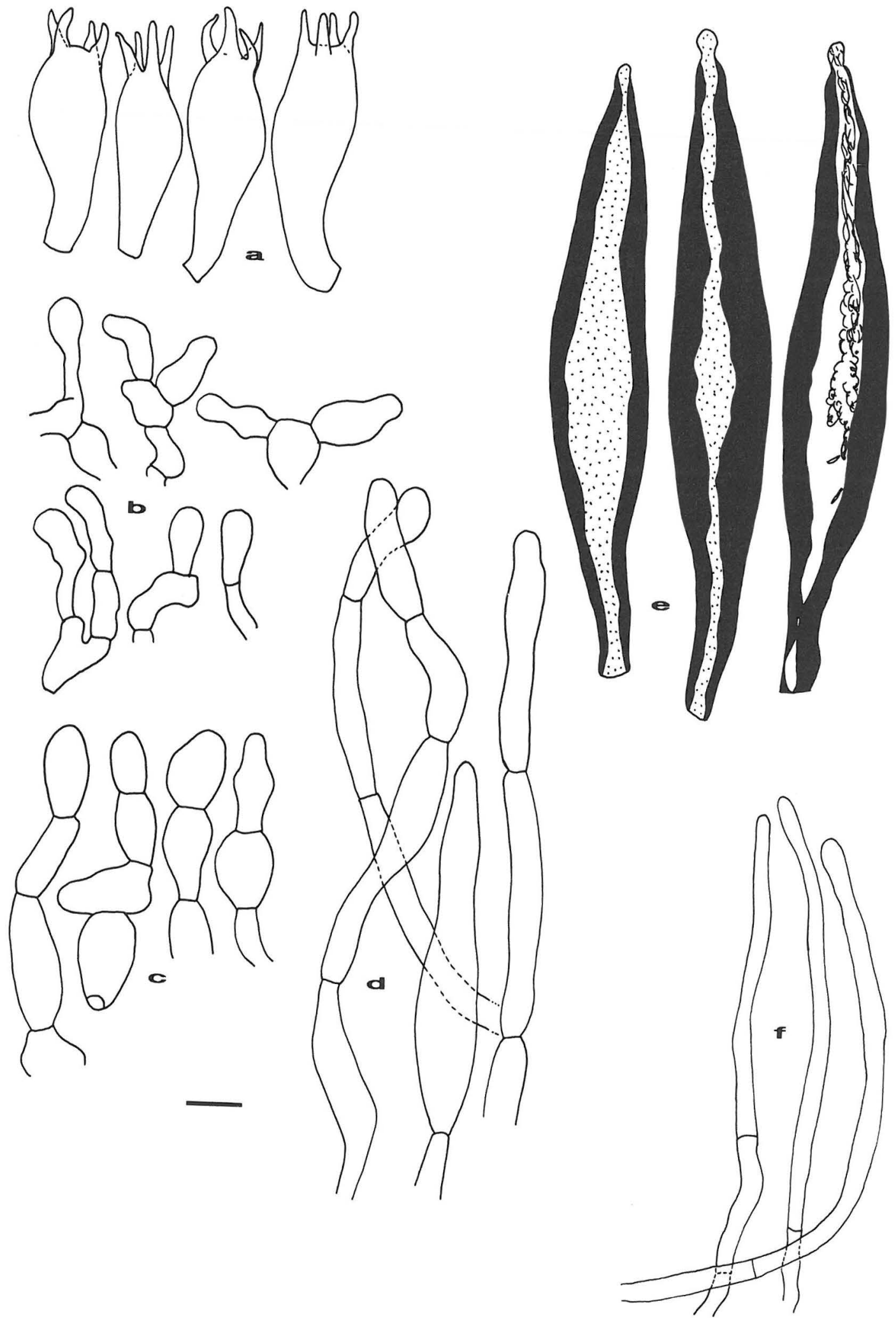
21. Russula usambarae Buyck, sp. nov. - Figs. $16,28,30$

Pileus $45 \mathrm{~mm}$ latus, brunneus, fortiter striatus ad marginem. Lamellae adnatae, usque ad $7 \mathrm{~mm}$ latae; acies brunnea. Stipes $50 \times 15 \mathrm{~mm}$, subcylindratus, brunneogriseus, cavus. Caro leviter acris, inodora, alba. Sporae in cumulo colore ignotae.

Sporae subglobosae ad breviter ellipsoideae, (9.2-)9.32-9.70-10.09(-10.9) x (8.1-)8.07$\underline{8.49}-8.91(-9.5) \mu \mathrm{m}(\mathrm{Q}=(1.06-) \underline{1.12}(-1.16))$, elementis firmis $1.5(2) \mu \mathrm{m}$ altis valde amyloideis generaliter acutoconicis dense dispositis interdum catenulatis vel raro connectis sursum rectis vel curvatis verrucibusque cylindratis obtusis parvioribus intermixtis ornatae; macula suprahilaris distincte amyloidea, verruculosa ad marginem, non decurrens. Basidia 30-45 x 11$14 \mu \mathrm{m}$, voluminosa sed brevia, tetraspora. Cystidia 100-130(-180) x (12-)15-20(-23) $\mu \mathrm{m}$, numerosa, conferta in acie, emergentia et valde distincta, fusiformia saepe capitulata, irregulariter sed valde crassotunicata, pariete in parte media 5-8(-10) $\mu \mathrm{m}$ lata extremitates versus attenuata praedita; sursum contentu SVamorpho-granulosa praedita. Pileipellis orthochromatica in azureo cresylico; pileocystidia non observata; subpellis paulum differentiata; suprapellis extremitatibus irregulariter ramosis brevibus ex 2-3 cellulis ellipsoideis clavatis vel irregulariter inflatis $5-10 \mu \mathrm{m}$ latis pigmento brunneo repletis compositis efformata. Stipitipellis elementis longioribus subcylindratis efformata; cellula terminalis clavata vel apicem versus gradatim attenuata; caulocystidia non observata.

Holopytus: Tanzania. Tanga Prov.: Lushoto Distr., W Usambara Mts, Mazumbai, $\mathrm{N}$ of the Mazumbai Forest Reserve border and Kambi Falls, Kwamshundi, lower montane forest, $1710-1800$ m, 8.XII.1989 Saarimäki 430 (H).

Pileus $45 \mathrm{~mm}$ in diam, brown, strongly striate towards the margin. Lamellae adnate, up to $7 \mathrm{~mm}$ broad, with a dark brown edge. Stipe $50 \times 15 \mathrm{~mm}$, subcylindrical, brownish grey, hollow. Flesh thin in the pileus, white; taste faintly sharp. Spore deposit not obtained.

Spores subglobose to broadly ellipsoid, (9.2-)9.329.70-10.09(-10.9) x (8.1-)8.07- $\underline{8.49-8.91(-9.5)}$ $\mu \mathrm{m}(\mathrm{Q}=(1.06-) \underline{1.12}(-1.16))$, with firm, strongly amyloid, usually conical and acute ornaments, densely disposed, often grouped by two or three, often curved in the upper portion, very variable in size, up to $1.5(2) \mu \mathrm{m}$ high, mixed with cylindrical and more or less blunt to very small verrucae, some ornaments interconnected by rare and very subtile connections visible only at high magnifications; suprahilar spot distinctly greying in Melzer's Reagent, verruculose at the border, not decurrent on hilar appendix. Basidia 30-45 x 11-14 $\mu \mathrm{m}$, rather voluminous but short, bearing large prominent sterigmata, 4-spored. Cystidia 100-130(-180) x (12-)15-20(-23) $\mu \mathrm{m}$, numerous, crowded at the edge, very prominent and emergent, fusoid, often capitulate, lamprocystidioid with irregularly thickened walls; wall reaching $5-8(-10) \mu \mathrm{m}$ in the broadest part of the cystidium, narrowing toward the cystidium extremities; in upper part with granular amorphous SV-contents. Pileipellis composed of a badly individualised subpellis without cystidial elements; suprapellis composed of short, irregularly branched extremities of two or three ellipsoid, clavate to irregularly inflated elements, $5-10 \mu \mathrm{m}$ in diam, usually containing a brown diffuse pigment. Stipitipellis composed of longer, subcylindrical elements; the terminal cell either clavate or gradually tapering towards the apex; caulocystidia not observed.

Vernacular names. Unknown.

Edibility. Unknown.

Ecology. Humid lower montane forest.

Likely hosts. Unknown.

Material examined: Tanzania. Tanga Prov.: holotype.

Observations. The most prominent feature of this species is undoubtedly the possession of well differentiated lamprocystidia on both the edge and sides of lamellae - a unique feature in Russula. Only two species of Russula are known to possess lamprocystidia on the edge of the lamellae. They are placed in the exclusively tropical subsect. Guayarenses Singer (see Buyck 1993b), including two African species described from the Zaïrean rain forest. $R$. usambarae resembles $R$. lamprocystidiata Buyck, one of the two African members of subsect. Guayarenses, in the very dark brown, tomentose pileipellis, but differs in spore ornamentation and elements of the pileipellis.

Although the subsection Guayarenses is provisionally placed in section Heterophyllae it might be better put in section Crassotunicatae or section Fistulosae. 


\section{Habitats of Russula in Tanzania}

Russula specimens could be found in two kinds of habitats, that is in montane forests of Tanga Province and Northern Province and in miombo woodlands of Western Province, Lake Province and Southern Highlands Province.

\section{Montane forests}

\section{Tanga Province}

Mazumbai Forest Reserve in the West Usambara Mts is situated at an elevation of $1380-1900 \mathrm{~m}$ with mean annual rainfall of ca. $1230 \mathrm{~mm}$. It is mainly montane rain forest on rugged rocky escarpment. Soils are humic, ferriferous.

There is great variation in vegetation with elevation. At lower elevations Syzygium guineense, Isoberlinia scheffleri, Parinari excelsa, Allanblackia stuhlmannii, Newtonia buchananii and Entandrophragma excelsum are locally common trees. In many isolated cases Ocotea usambarensis is the dominant tree, but heavily harvested for timber. The valleys are particularly rich in species; Cyathea manniana is common. At lower elevations common species include Dracaena steudneri, Neoboutonia macrocalyx, and introduced trees of Khaya nyasica.

At higher elevations the main tree species include Ocotea usambarensis, Agauria salicifolia, Rapanea melanophloeos and Syzygium guineense to $1600 \mathrm{~m}$. Above this elevation Podocarpus latifolius becomes dominant with Syzygium standthii. Towards the top Maytenus acuminata, Bersama abyssinica and Dombeya torrida become typical besides the ericaceous scrubs. Olea capensis and Juniperus procera indicate the dry montane forest belt.

The forest is very rich in epiphytic and terrestrial bryophytes and lichens. The shrub layer is also rich in species. It is particularly rich in rubiaceous shrubs like Pavetta, Psychotria, Chassalia and Pauridiantha. Endemics or nearendemics include Impatiens mazumbaiensis, Polystachya, Pavetta mazumbaiensis, so that this forest is important as the type locality for these taxa. Others in the shrub layer include Tabernaemontana and Whitfieldia. Costus, Aframomum, Calanthe, and the tall Ensete ventricosum are frequent forbs.

Mazumbai is perhaps the finest example of remaining primeval forest on the West Usambaras - a forest jewel to be preserved in
Northern Tanzania. When we were there in April 1991, there was, however, a lot of forest clearing for fields and tree felling for timber, especially Podocarpus and Ocotea.

\section{Northern Province}

Mt Meru, W slope. In contrast to the old crystalline rocks of the West Usambaras, Mt Meru is a volcanic mountain of more recent origin, with richer soils and poorer flora. Russula specimens were found only in exotic Pinus plantations at an elevation of $1900 \mathrm{~m}$.

\section{Miombo woodlands}

\section{Southern Highlands Province}

Mbozi lies on a $1600 \mathrm{~m}$ high plateau with isolated hills. Fertile clay loam soils with good drainage dominate. Much of the original vegetation is cleared for fuel wood, building poles and for cultivation. The woodland remnants are mainly composed of shrubs of Combretum, Isoberlinia angolensis, Julbernardia paniculata and locally common are Brachystegia floribunda, B. spiciformis and Uapaca pilosa. Hyparrhenia and Cymbopogon are common grasses of the deciduous woodland. The herbaceous shrubs and annuals include Psychotria and Dyschoriste species.

Ipembe Hill, $25 \mathrm{~km}$ east of Mbeya town, lies at an elevation of $1760-1840 \mathrm{~m}$. Soil is clay loam with good drainage, reddish brown on the uplifted volcanic hill. Vegetation is heavily grazed deciduous woodland with scattered trees of Uapaca kirkiana, Brachystegia species, and Parinari curatellifolia. The few shrubs include Clutia abyssinica, which is an indicator of old forest areas. Peucedanum heracleoides, Triumfetta, and Lactuca species are common herbs. All grasses had been grazed to the ground.

\section{Lake Province}

Buharahara, a few kilometres west of Geita, lies at an elevation of $1250 \mathrm{~m}$. A hill slope with black soils was visited. Deciduous woodland is composed of Combretum molle, C. collinum, Terminalia sericea, Crossopteryx febrifuga, Brachystegia species and Commiphora africana as dominant tree species. 

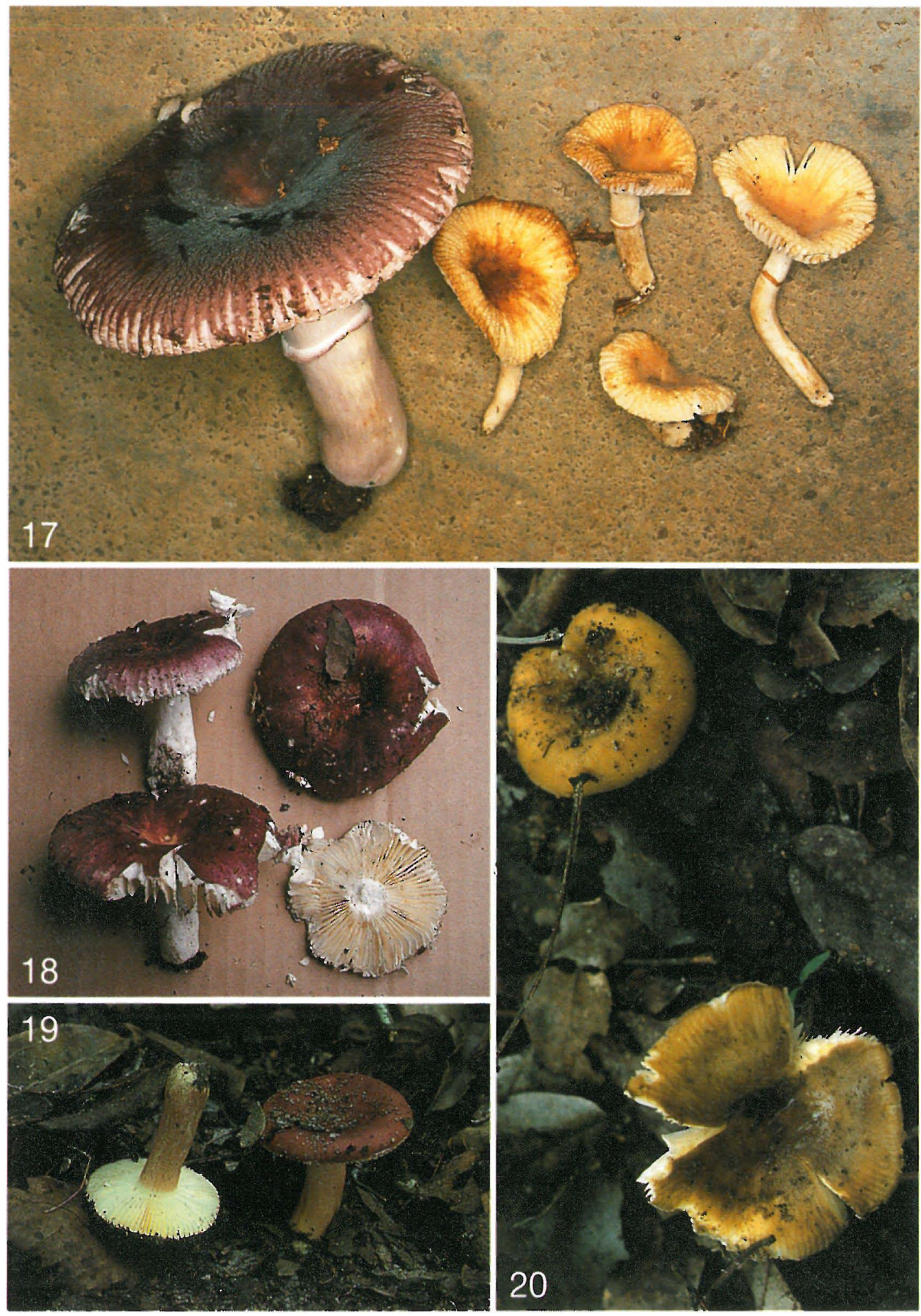

Figs. 17-20. Fruit bodies of Tanzanian Russula species. - 17: R. annulata s.l. (10113) on left, on right 4 fruit bodies of R. acriannulata (type). - 18: Russula echinosperma (913). - 19: R.congoana (1040). - 20: R. ciliata (1119). 

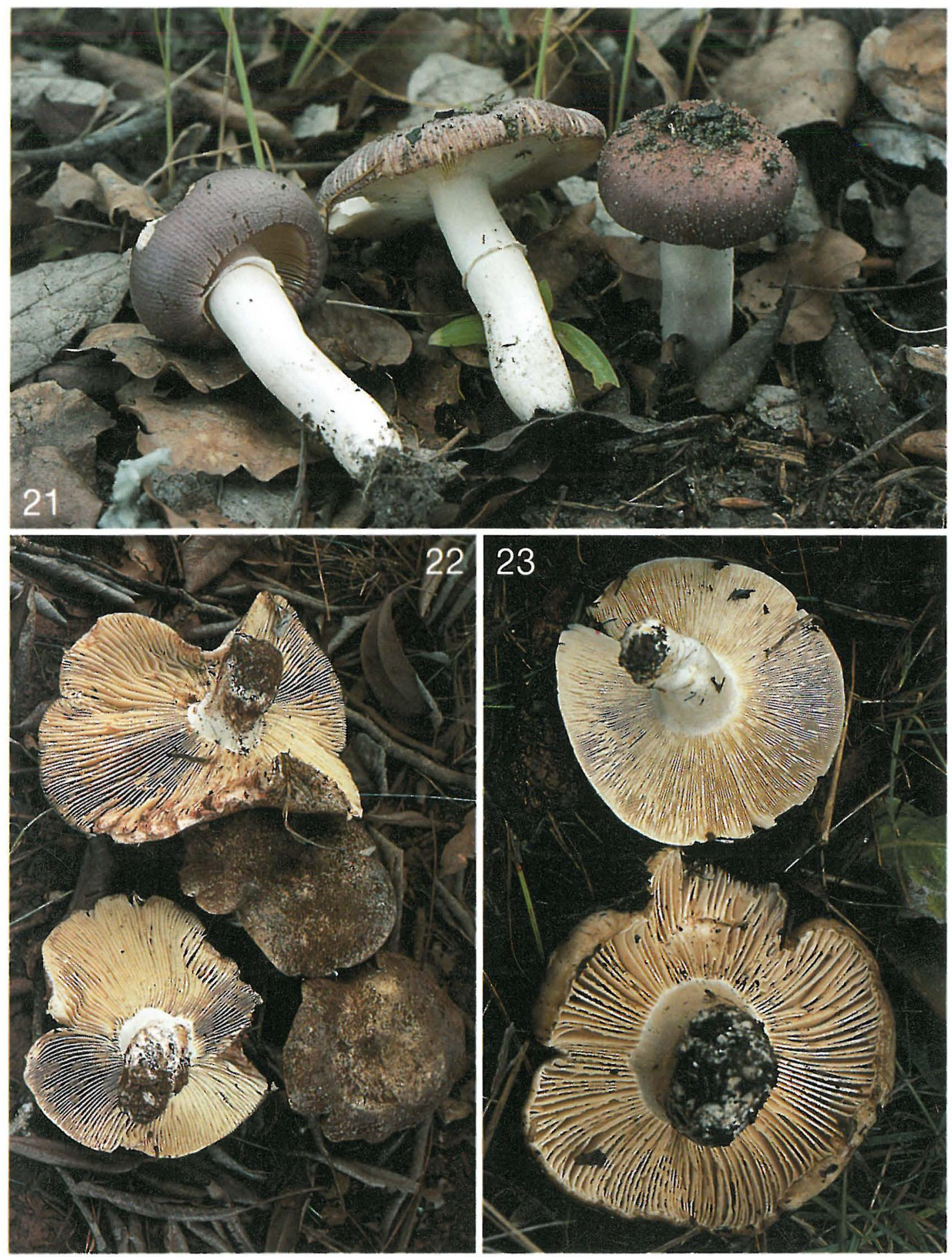

Figs. 21-23. Fruit bodies of Tanzanian Russula species. - 21: R. hiemisilvae (type). - 22: R. phaeocephala (1007a). 23: $R$. liberiensis (755) above, $R$. heimii (745) below. 

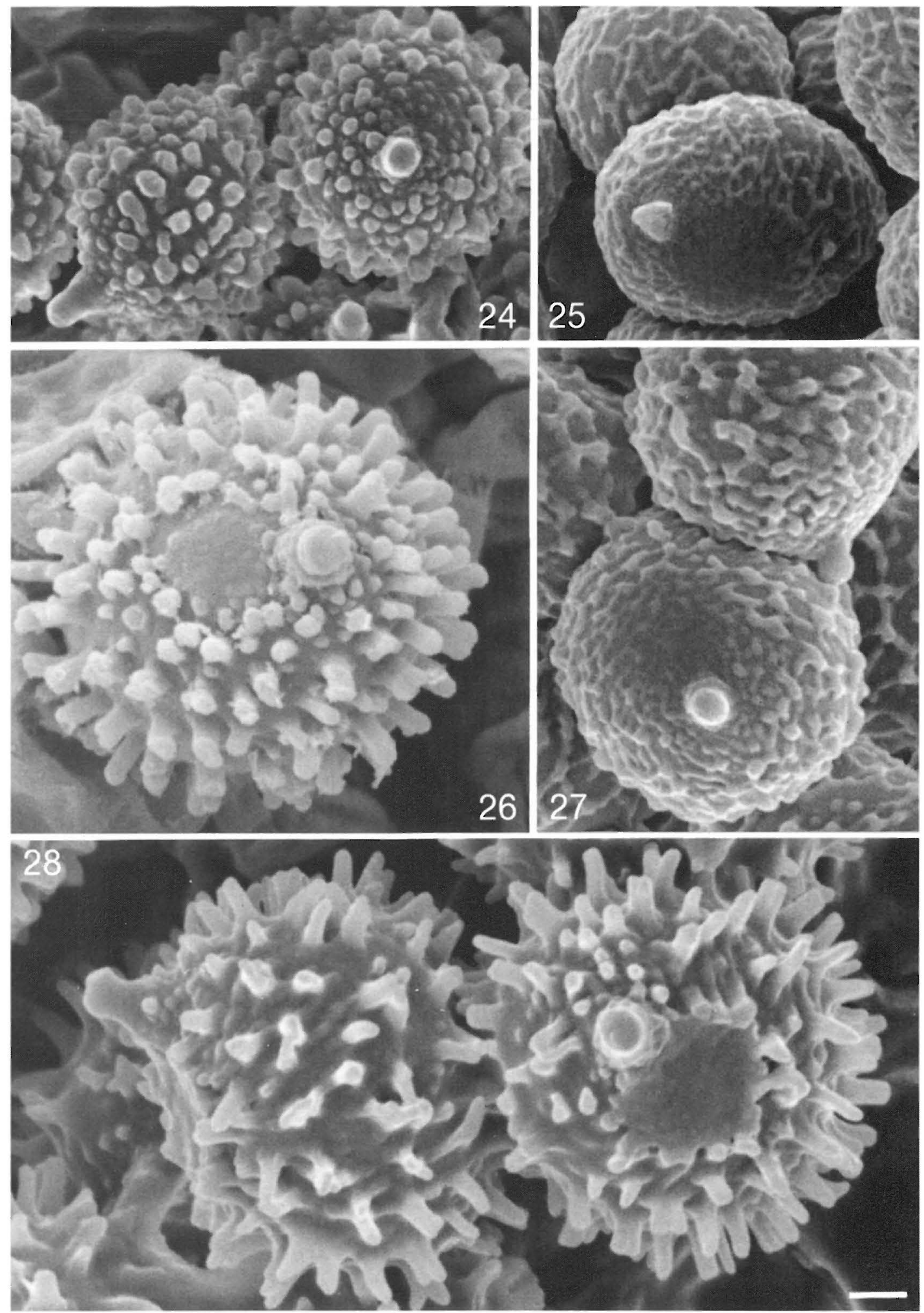

Figs. 24-28. Spore ornamentation as seen with scanning electron microscope. $-24:$ Russula tanzaniae (type). $-25: R$. sublaevis (1105b). - 26: R. acriannulata (type). - 27: R. tenuithrix (type). $-28: R$. usambarae (type). Bar $=1 \mu \mathrm{m}$. 

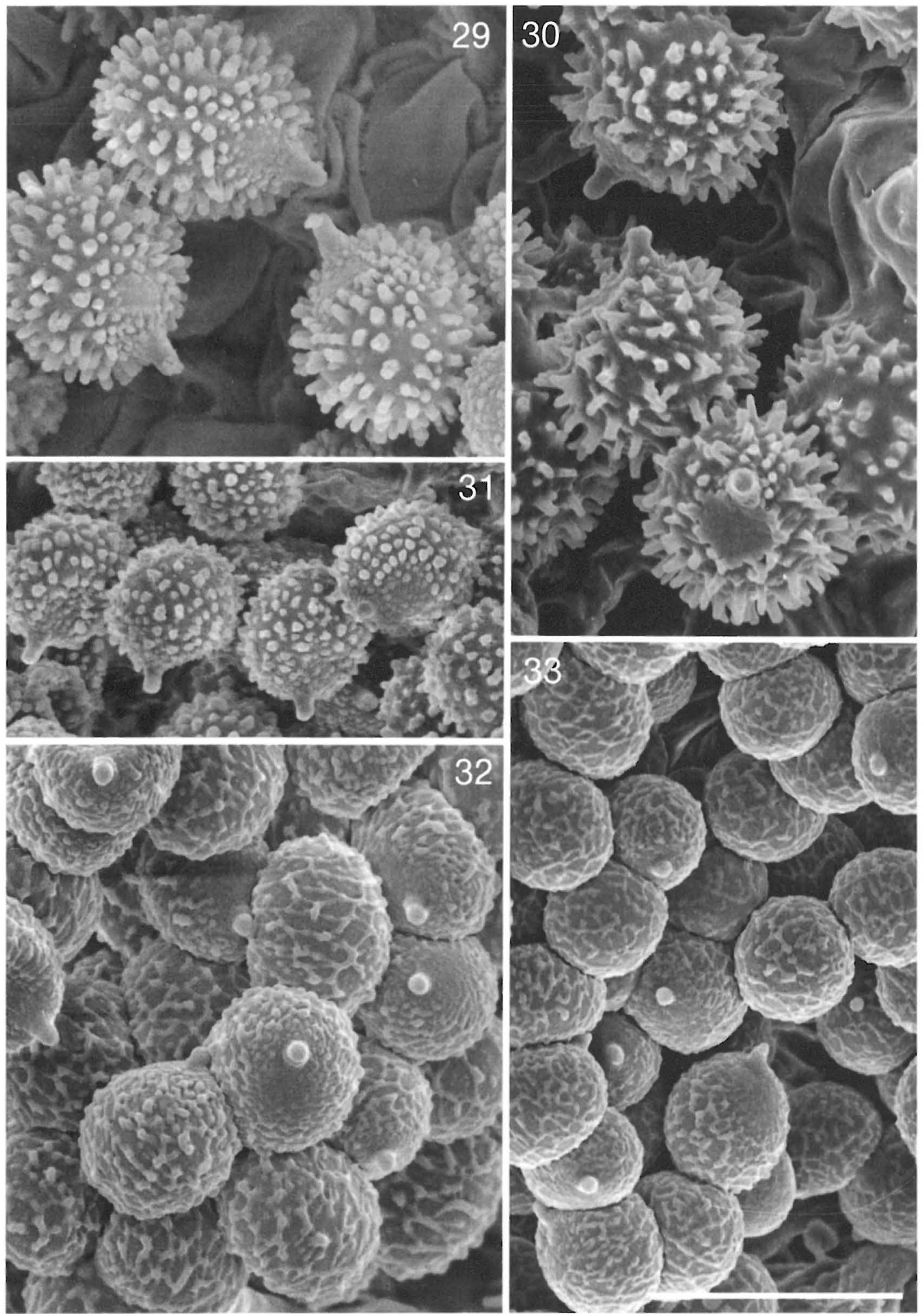

Figs. 29-33. Spore ornamentation as seen with scanning electron microsope. -29 . Russula acriannulata (type). -30 . R. usambarae (type). - 31. R. tanzaniae (type). - 32. R. tenuithrix (type). - 33. R. sublaevis $(1105 b)$. Bar $=10 \mu \mathrm{m}$. 


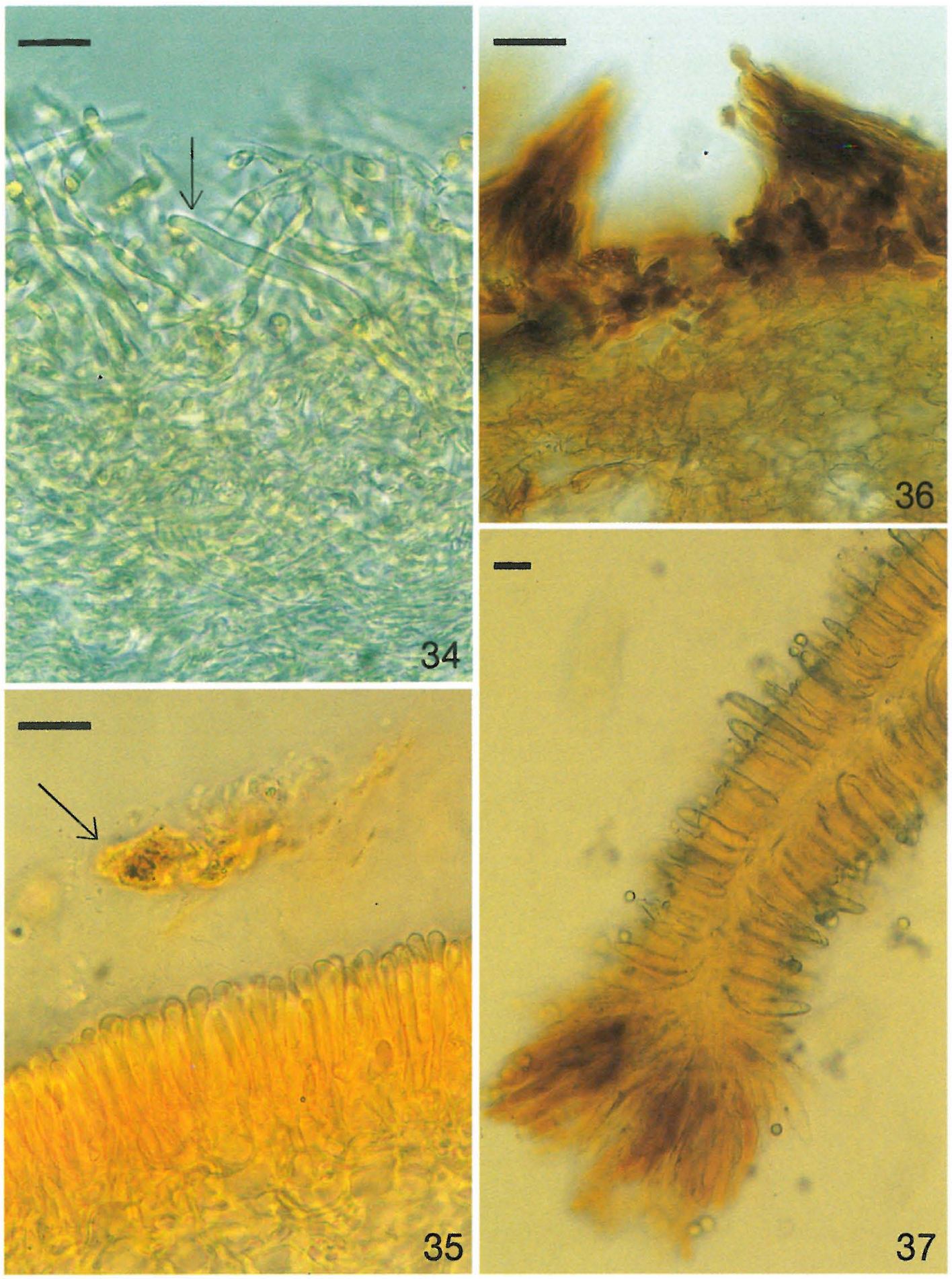

Figs. 34-37. Microscopic details. - 34: Russula tenuithrix (type). Detail of densely interwoven hyphal extremities of suprapellis in pileus center. In foreground (arrow) a dermatocystidium ascending from subpellis. -35 . R. cellulata (1105a). Remark debris (arrow) showing mucus layer on top of suprapellis. - 36: Russula subfistulosa (10121). Section through pileipellis showing clusters of hyphal extremities. - 37: Russula subfistulosa (1012I). Detail of a section near lamella edge showing very abundant cystidia on sides of lamella which are well characterized by their abundant contents and sometimes very deeply inserted in lamellar trama. Lamella edge is entirely occupied by large pigmented marginal cells which are in all respects similar to hyphal extremities of pileipellis. Bar $=20 \mu \mathrm{m}$. 


\section{Western Province}

Wendele, about $30 \mathrm{~km}$ west of Kahama, lies at the altitude of ca. $1200 \mathrm{~m}$. The topography is flat to undulating with a few small rocky hills. Sandy clay loam soils with imperfect drainage prevail, having a high water table which supplies water to wells that have been dug. The deciduous woodland is mainly composed of Brachystegia species, Combretum, Boswellia, Pterocarpus angolensis, Pseudolachnostylis maprouneifolia, Xeroderris stuhlmannii and a few species of Strychnos.

Mpunze Forest Reserve, about $40 \mathrm{~km} \mathrm{SW}$ of Kahama town, lies at an elevation of $1150 \mathrm{~m}$. Topography is undulating with a few stony hills. Reddish brown sandy clay soils prevail. Vegetation is deciduous woodland with Brachystegia, Combretum, Crossopteryx, Catunaregam, Annona senegaensis, Strychnos, Pterocarpus angolensis and many saplings especially of Pterocarpus. The bushy Combretum vegetation appears frequently, as well as some Acacia bushland. (The mushrooms were completely absent in Acacia bushland). Emergent palms of Hyphaene petersiana occur occasionally in open vegetation on patches of alkaline sandy clay brown soils with a high water table (no mushrooms under them).

Lulanguru, $20 \mathrm{~km} \mathrm{~W}$ of Tabora, lies at an elevation of $1100 \mathrm{~m}$. Topography consists of undulating land with isolated hills. Soil is brown sandy loam with a discontinuous iron pan. Vegetation is deciduous woodland. Common tree species include Brachystegia, Combretum, Antidesma, Anisophyllea, Annona, Ochna, Lonchocarpus, Terminalia, Vitex, Strychnos, Lannea and shrubs like Dichrostachys and the liana Strophanthus kombe.

\section{Edibility}

\section{Edibility of Russula species in Tanzania}

After 81 complete interviews and several shorter inquiries we have come to the conclusion that habits of mushroom use within each individual tribe are always very uniform, but differ greatly between tribes inhabiting different areas. Most of the rural Tanzanians include mushrooms in their diet. Of the 28 tribes queried thus far only the following reject use of mushrooms: the Chagga, Maasai, Meru, and Arusha. The information compiled from the interviews will be published after the fourth and last collecting trip in 1993.
In neither of the montane areas visited are Russula species used for food. Mt Meru in Northern Province is inhabited by Arusha and Meru people who reject all mushrooms. In Mazumbai in the West Usambara Mountains people belong to the Sambaa tribe. We made several collecting forays there with local people and saw many specimens of Russula. All were considered inedible, although Sambaa people eat a wide variety of different mushrooms even including some polypores.

In the miombo woodland areas we visited, Russula were usually considered edible, but not all species. The interviews from that area were, however, so few that only preliminary conclusions can be drawn. Fresh Russula specimens were displayed and their edibility was discussed during 12 interviews with people from the following tribes: the Bena, Nyiha, Safwa, Nyamwezi, Sumbwa and Sukuma (see Fig. 4).

Most of the interviewees chose the same practice for identification that is familiar to Russula researchers all over the world. They broke the specimen, smelt and tasted it before stating their opinion. Some species were edible, some were inedible. Some interviewees treated several Russula species as a group, explaining that certain species have many colour variations. On the other hand some brownish species of Russula were in the Sukuma language called Kansalaghe, which is a general name for inedible or poisonous mushrooms. The vernacular names and edibility or inedibility from the interviews are added after the descriptions of the species.

We could not discover on which characters the edibility of Russula species was based.

People were asked to estimate the deliciousness for food of different mushrooms on a scale from 1 to 3 . Usually Termitomyces species got the best ratings. Species of Russula were obviously rated average. Only twice was a Russula species judged delicious with three points and twice valued lower, with only one point.

\section{Edibility of Russula species elsewhere}

In other countries of tropical Africa many Russula species are appreciated and intensively sought after as food. From Malawi Williamson (1975) and Morris (1984, 1987, 1990, 1992, 1993) have recorded several edible Russula species with vernacular names. Some of the species are sun-dried or parboiled before 
cooking. Pegler and Piearce (1980) and Piearce (1981) state that in Zambia the family Russulaceae accounts for a significant proportion of mushrooms, but many species are considered inedible owing to their peppery or otherwise unpleasant taste. Despite this fact, dried mushrooms offered for sale in town markets during the dry season consist mainly of Russulaceae, together with chanterelles. In some parts of Zambia, species of Russula are smoked before storage. In Zaïre Russula is one of the genera most often eaten (Parent \& Thoen 1977). Buyck (1989e) lists in his work on the genus Russula several species used for food by natives in Central Africa.

In the book on common names of edible mushrooms in various languages Chandra (1989) states that many species of Russula are consumed by the Slavic people of eastern Europe. In Russia, as well, many acrid species are considered edible when salted (Serzanina \& Zmitrovic 1978). A rule that nearly all species of Russula are edible, but the acrid ones must be parboiled, is common among some non-Slavic East European nations, at least in Finland (Korhonen 1989) and Estonia (Kalamees 1966, 1976). Kalamees (1966) considers the very acrid Russula emetica poisonous when fresh, but edible when boiled. For young specimens it is recommended they be boiled twice, and after that they are very tasty when marinated.

The Italians view Russula emetica with suspicion, because it contains some thermolabile compounds which irritate the digestive system (Fenaroli 1964, Auguadri et al. 1984). They state that acrid taste is a sufficient indication to avoid a Russula. In Germany (Haas 1982) a taste-test is always recommended before using any Russula species for food. In Czech and Slovakia (Kotlaba 1980, Svrček et al. 1984) the situation is the same, but Romagnesi (1962) thinks that some acrid species of Russula can be used in small amounts as a spice. Anglo-American mushroom guides (Phillips 1991, Miller 1978, Groves 1962) recommend that bitter Russula species be rejected. Stadelman et al. (1976) report $R$. emetica to contain muscarine and epi-muscarine. Bresinsky and Besl (1990), however, consider such findings doubtful. In a Swedish book on poisonous mushrooms (Persson et al. 1987), $R$. emetica receives a straight-forward characterization as poisonous. Its Swedish name, giftkremla, means literally a poisonous Russula.
In China several species of Russula are consumed and can be often purchased in market places (Yu-Cheng Dai, personal communication). $R$. emetica is considered poisonous also in China (Xie et al. 1986). One species, Russula subnigricans Hongo, is considered to be deadly poisonous (Anonymous 1991), causing the following symptoms: nausea, dizzines, weakness, muscular and stomach pains, unconsciousness and sometimes death.

In Japan many Russula species are considered edible (Imazeki et al. 1988). Russula subnigricans is there also reported to be deadly poisonous. Imazeki et al. (1988) and Hongo (1960) give the following symptoms of poisoning: nausea, dysentery with bloody urine, constriction of the pupils, weakening of pulse, unconsciousness and death after a couple of days. Eating of 2-3 fruitbodies can be fatal.

\section{Discussion}

The high diversity of the African Russulae is well illustrated in the present material by the amazing amount of 21 Russula species found among only 36 randomly gathered specimens. Many more species can be expected to be found in Tanzania, especially in large areas of the woodlands dominated by ectomycorrhizal trees belonging to such genera as Brachystegia, Julbernardia, Isoberlinia, and Uapaca.

There is surprisingly close agreement between the microscopic features of the Tanzanian collections and those that were described by Buyck (1989e, 1993b) on material from other tropical African countries of the same species.

Buyck (1993a) is convinced that as far as indigenous African vegetation is concerned, all Russula species are native. The few exotic species of the Russulaceae are in tropical Africa always associated with Pinus plantations and appear to be unable to extend the type of their hosts by invading the natural forest. The native Russula species seem to be incompatible with plantations of exotic trees.

Virtually nothing is yet known about host specificity of species of Russula or any other ectomycorrhizal species in tropical Africa (Buyck et al. 1993). A large number of Russula probably exhibit a very wide host range and are found over large areas within either woodland vegetation or rain forest. It is not clear whether some species occur both in the rain forest and in the surrounding woodlands, but if that happens it 
is certainly not a frequent phenomenon. This is also confirmed by the Tanzanian collections: the lower montane rain forest appears to be principally inhabited by Russula species described from the equatorial rain forest, whereas collections from the miombo woodlands involve mostly species that are known only from the Zambesian woodlands and have not yet been found in the rain forest area.

We cannot yet make any general rule about the edibility of Russula species in Tanzania. On our next trip we intend to pay special attention to ways that people judge Russula species. Do they choose them mainly by the colour or smell or taste of a species? Don't they mind the acrid taste, and if so, does the taste disappear after boiling?

Acknowledgements. We want to thank Professor Arvi Hurskainen (Department of Asian and African Studies, University of Helsinki) for revising the orthography of the vernacular names of our Tanzanian Russula species. Ms. Vanamo Salo, M.Sc. helped in taking the SEM photographs. For the translation of Chinese and Japanese texts we thank Mr. Yu-Cheng Dai, M.Sc. Professor Teuvo Ahti translated for us the Russian, Prof. Jan Jeník the Czech, and Mr. Gerry Massa the Italian language. Mrs. Hendrika Buyck we thank for practical assistance. The Finnish International Development Agency funded the research, and the Academy of Finland financed the second author's visit to Finland. Dr. Carol Norris revised the English text.

\section{References}

Anonymous 1987: Atlasi kwa shule za msingi. Tanzania. - 65 pp. International Development Association, Tanzania.

Anonymous 1990: Kenya to Zimbabwe. - The Europa world yearbook 31(2): 1521-3034.

Anonymous 1991: Edible fungal flora of China. (In Chinese). - 298 pp. China Forestry Publishing House, Beijing.

Auguadri, A., Lucchini G., Riva, A., Testa, E. 1984: Funghi e boschi del Cantone Ticino 1. - 261 pp. Gaggini-Bizzozero, Lugano.

Beeli, M. 1928: Contribution à l'étude de la flore mycologique du Congo 5. Fungi Goossensiani. - Bull. Soc. Roy. Bot. Belgique 60:153-169.

Beeli, M. 1936: Contribution à l'étude de la flore mycologique du Congo 11. Fungi Goossensiani. - Bull. Jard. Bot. Etat 14:83-91.

Berry, L. (ed.) 1975: Tanzania in maps. - 172 pp. Univ. London Press, London \& Nairobi.

Bresinsky, A. \& Besl, H. 1990: A colour atlas of poisonous fungi. - 295 pp. Wolfe Publishing, London.

Buyck, B. 1988: Russules nouvelles d'Afrique Centrale. Bull. Jard. Bot. Nat. Belgique 58:467-476.

Buyck, B. 1989a: Valeur taxonomique du bleu de crésyl pour le genre Russula - Bull. Soc. Mycol. France 105:1-6.
Buyck, B. 1989b: Quelques Russules à lamprocystides. Mycotaxon 35:45-54.

Buyck, B. 1989c: Etude microscopique de Russules tropicales: Mimeticinae subsect. nov. - Mycotaxon 35:55-63.

Buyck, B. 1989d: New taxa of Central African Russulaceae. - Bull. Jard. Bot. Nat. Belgique 59:241-253.

Buyck, B. 1989e: Révision du genre Russula en Afrique centrale. - Ph.D. dissertation, Rijksuniversiteit Gent, Part 1: 1-318; part 2a: 1-310; part 2b: 311-590 (mimeo.).

Buyck, B. 1990a: Nouveaux taxons infragénériques dans le genre Russula Persoon en Afrique centrale. - Bull. Jard. Bot. Nat. Belgique 60:191-211.

Buyck, B. 1990b: New taxa of tropical Russulae: Pseudoepitheliosinae subsect. nov. - Mycotaxon 39:317327.

Buyck, B. 1991a,: The study of microscopic features in Russula. 1. Spores and basidia. - Russulales Newsletter 1:8-26

Buyck, B.(1991b); The study of microscopic features in Russula. 2. Sterile cells of the hymenium. - Russulales News 1:62-85 (1991b).

Buyck, B. 1992: Checklist of tropical Russulae and their type specimens. - Russulales News Spec. Issue 1:199.

Buyck, B. 1993a: Ectotrophy in tropical African ecosystems. - Proc. 13th AETFAT Congress, Zomba, Malawi, 1991 (in press).

Buyck, B. 1993b: Russula. - Flore Illustrée des Champignons d'Afrique Centrale, fasc. 15-17, figs. 210-364, pl. 55-93 (in press).

Buyck, B., Thoen, D. \& Watling R. 1993: Ectomycorrhizal fungi: a case study. In: The lowland rain forest of the Guinea-Gongo domain. - Proceedings of the Royal Society of Edinburgh (in press).

Chandra, A. 1989: Elsevier's dictionary of edible mushrooms. Botanical and common names in various languages of the world. - 259 pp. Elsevier, Amsterdam.

Fenaroli, L. 1964: I funghi. - 266 pp. Aldo Martello, Milano.

Groves, W. 1962: Edible and poisonous mushrooms of Canada. -298 pp. Canada Dept. Agric., Ottawa.

Haas, H. 1982: Pilze Mitteleuropas. - 303 pp. Verlag Das Beste, Stuttgart.

Härkönen, M. 1992: Wild mushrooms, a delicacy in Tanzania. - Univ. Helsingiensis 12:29-31.

Härkönen, M. \& Saarimäki, T. 1991: Tanzanian Myxomycetes: first survey. - Karstenia 31:31-54.

Härkönen, M. \& Saarimäki, T. 1992: Tanzanian Myxomycetes: first survey (addition). - Karstenia 32:6.

Härkönen, M., Saarimäki, T. \& Mwasumbi L. 1993a: Setting up a research project on Tanzanian mushrooms and their use. - Proc. 13th AETFAT Congress, Zomba, Malawi, 1991 (in press).

Härkönen, M., Saarimäki, T., Mwasumbi, L. \& Niemelä, T. 1993b: Collection of Tanzanian mushroom heritage as a developmental cooperation between the universities of Helsinki and Dar es Salaam. - Aquilo (in press).

Heim, R. 1938a: Prodrôme à une flore mycologique de Madagascar et dépendances 1. Les Lactario-russulés 
du domaine oriental de Madagascar: essai sur la classification et la phylogénie des Astérosporales. 196 pp., 59 figs., 4 col. pl., Paris.

Heim, R. 1938b: Diagnoses latines d'espèces et variétés nouvelles de Lactario-Russulés du domaine oriental de Madagascar. - Candollea 7:374-394.

Heim, R. 1943: Remarques sur les formes primitives ou dégradées de Lactario-russulés tropicaux. - Boissiera, suppl. Candollea 7:266-280.

Heim, R. 1968: Breves diagnoses latinae novitatum genericarum specificarumque nuper descriptarum, quatrième série. - Rev. Mycol. 33:211-217.

Heim, R. 1970(1969): Breves diagnoses latinae novitatum genericarum specificarumque nuper descriptarum, sixième série. - Rev. Mycol. 34:343-347.

Heim, R. 1971: Breves diagnoses latinae novitatum genericarum specificarumque nuper descriptarum, septième série. - Rev. Mycol. 36:128-131.

Hennings, P. 1901: Fungi Africae orientalis. - Engl. Bot. Jahrb. 28:318-329.

Hennings, P. 1902: Fungi camerunenses 3. - Engl. Bot. Jahrb. 30:36-57.

Hongo, T. 1960: The Agaricales of Japan 1-3. Russulaceae. - Acta Phytotax. Geobot. 18:129-146.

Imazeki, R., Otani, Y. \& Hongo, T. 1988: Fungi of Japan. (In Japanese). - 624 pp. Yama-Kei Publishers, Tokyo.

Kalamees, K. 1966: Seened. - 296 pp, 60 pls. Valgus, Tallinn.

Kalamees, K. 1976: Meie seeni. - 144 pp. Valgus, Tallinn.

Korhonen, M. 1989: Uusi sienikirja. - 318 pp. Otava, Helsinki.

Kotlaba, F. 1980: Unsere Pilze. - 360 pp. Albatros, Praha.

Leistner, O \& Morris, J. 1976: Southern African place names, - Annals of the Cape Provincial Museum $12: 1-565$.

Miller, O.K. Jr. 1978: Mushrooms of North America. 368 pp. E.P. Dutton, New York.

Morris, B. 1984: Macrofungi of Malawi: some ethnobotanical notes. - Bull. British Mycol. Soc. 18:4857.

Morris, B. 1987: Common mushrooms in Malawi. - 108 pp. Fungiflora, Oslo.

Morris, B. 1990: An annotated check-list of the macrofungi of Malawi. - Kirkia 13:323-364.

Morris, B. 1992: Mushrooms: for medicine, magic and munching. - Nyala 16(1): 1-8

Morris, B. 1993: Bowa: ethnomycological notes on the macrofungi of Malawi. - Proc. 13th AETFAT Congress, Zomba, Malawi, 1991 (in press).

Parent, G. \& Thoen, D. 1977: Food value of edible mushrooms from Upper Shaba region. - Econ. Bot. 31:436-445.

Patouillard, M.N. 1914: Quelques champignons du Congo. - Bull. Soc. Mycol. France 30:336-346.

Patouillard, M.N. 1928: Contribution à l'étude des champignons de Madagascar. - Mém. Acad. Malgache 6:1-49.

Pegler, D.N. 1977: A preliminary agaric flora of East Africa. - Kew Bull. Add. Ser. 6:1-615. HMSO, London.
Pegler, D.N. 1983: Agaric flora of the Lesser Antilles. Kew Bull. Add. Ser. 9:1-688. HMSO, London.

Pegler, D.N. \& Piearce, G.D. 1980: The edible mushrooms of Zambia. - Kew Bull. 35:475-491.

Perreau, J. 1983: Russula coffeata sp. nov. d'Afrique occidental subéquatorial. - Cryptogamie, Mycol. 4:157-164.

Persson, H., Holmberg, P., Marklund, H. \& Muskos S. 1987: Giftsvampar och svampgifter. - 56 pp. ColorTryck, Härnösand.

Phillips, R. 1991: Mushrooms of North America. - 319 pp. Little, Brown and Company, Toronto.

Piearce, G.D. 1981: An introduction to Zambia's wild mushrooms. - 28 pp. Forest Dept., Ndola.

Polhill, D. 1988: Flora of East Tropical Africa. Index of collecting localities. - 398 pp. Royal Bot. Gardens, Kew.

Romagnesi, H. 1962: Petit atlas des champignons. -418 pp. Bordas, Vevey.

Romagnesi, H. 1967: Les Russules d'Europe et d'Afrique du Nord. - 998 pp. Bordas, Paris.

Romagnesi, H. 1985: Les Russules d'Europe et d'Afrique du Nord, suppl. edition, with an English translation of the keys by R.W.G. Dennis. - $64+1030$ pp., 1 pl., 1129 fig. Kramer, Vaduz.

Serzhanina, G.I. \& Zmitrovic, I.I. 1978: Makromitsety. Illyustrirovannoe posobne dlya bilogov. $-190 \mathrm{pp}$. Vysheishaya Shkola, Minsk.

Singer, R. 1935: Sur quelques Russules exotiques. - Ann. Crypt. Exotique 8:88-93.

Singer, R. 1942: Das System der Agaricales 2. - Ann. Mycol. 40:1-132.

Singer, R. 1955: Type studies on Basidiomycetes 8. Sydowia 9:367-431.

Singer, R. 1973: Diagnoses fungorum novorum Agaricalium 3. - Beih. Sydowia 7:1-106.

Singer, R. 1986: The Agaricales in modern taxonomy. 981 pp. Koeltz, Koenigstein.

Singer, R., Araujo, I.J.S \& Ivory, M.H. 1983: The ectotrophically mycorrhizal fungi of the neotropical lowlands, especially Central Amazonia. - Beih. Nova Hedwigia 77:1-352.

Stadelman, R.J., Müller, E. \& Eugster, C.H. 1976: Über die Verbreitung der stereomeren Muscarine innerhalb der Ordnung der Agaricales. - Helv. Chim. Acta 59:2432-2436.

Svrček, M., Erhart, J. \& Erhartová, M. 1984: Holubinky. - 165 pp. Academia, Praha.

Williamson, J. 1975: Useful plants of Malawi. Rev. ed. 336 pp. Univ. Malawi, Zomba.

White, F. 1983: The vegetation of Africa. - Unesco Nat. Resources Res. 20:1-356.

Xie, Z., Wang, Y. \& Wang, B. 1986: Illustrations of Agarics of Chang Bai Mountains, China (In Chinese). -288 pp. Jilin Sci. Technol. Press, Changchun.

Received on 12 March 1993 